\title{
Molecular biodiversity of cassava begomoviruses in Tanzania: evolution of cassava geminiviruses in Africa and evidence for East Africa being a center of diversity of cassava geminiviruses J Ndunguru ${ }^{1,2}$, JP Legg 3 , TAS Aveling ${ }^{4}$, G Thompson ${ }^{5}$ and CM Fauquet*2
}

\begin{abstract}
Address: ${ }^{1}$ Plant Protection Division, P.O. Box 1484, Mwanza, Tanzania, 2 International Laboratory for Tropical Agricultural Biotechnology, Donald Danforth Plant Science Center, 975 N. Warson Rd., St. Louis, MO 63132 USA, IInternational Institute of Tropical Agriculture-Eastern and Southern Africa Regional Center and Natural Resource Institute, Box 7878, Kampala, Uganda, ${ }^{4}$ Department of Microbiology and Plant Pathology, University of Pretoria, Pretoria 0002, South Africa and ${ }^{5}$ ARC-Institute for Industrial Crops, Private Bag X82075, Rustenburg 0300, South Africa
\end{abstract}

Email: J Ndunguru - jndunguru2003@yahoo.co.uk; JP Legg - jlegg@iitaesarc.co.ug; TAS Aveling - terry.aveling@fabi.up.ac.za; G Thompson - gthompson@arc.agric.za; CM Fauquet* - iltab@danforthcenter.org

* Corresponding author

Published: 22 March 2005

Virology Journal 2005, 2:21 doi:10.1186/|743-422X-2-21

This article is available from: http://www.virologyj.com/content/2/I/2I

(C) 2005 Ndunguru et al; licensee BioMed Central Ltd.

This is an Open Access article distributed under the terms of the Creative Commons Attribution License (http://creativecommons.org/licenses/by/2.0), which permits unrestricted use, distribution, and reproduction in any medium, provided the original work is properly cited.
Received: 31 January 2005

Accepted: 22 March 2005

\begin{abstract}
Cassava is infected by numerous geminiviruses in Africa and India that cause devastating losses to poor farmers. We here describe the molecular diversity of seven representative cassava mosaic geminiviruses (CMGs) infecting cassava from multiple locations in Tanzania. We report for the first time the presence of two isolates in East Africa: (EACMCV-[TZI] and EACMCV-[TZ7]) of the species East African cassava mosaic Cameroon virus, originally described in West Africa. The complete nucleotide sequence of EACMCV-[TZI] DNA-A and DNA-B components shared a high overall sequence identity to EACMCV[CM] components $(92 \%$ and $84 \%)$. The EACMCV-[TZI] and -[TZ7] genomic components have recombinations in the same genome regions reported in EACMCV-[CM], but they also have additional recombinations in both components. Evidence from sequence analysis suggests that the two strains have the same ancient origin and are not recent introductions. EACMCV-[TZI] occurred widely in the southern part of the country. Four other CMG isolates were identified: two were close to the EACMVKenya strain (named EACMV-[KE/TZT] and EACMV-[KE/TZM] with $96 \%$ sequence identity); one isolate, TZI0, had 98\% homology to EACMV-UG2Svr and was named EACMV-UG2 [TZIO]; and finally one isolate was $95 \%$ identical to EACMV-[TZ] and named EACMV-[TZ/YV]. One isolate of African cassava mosaic virus with $97 \%$ sequence identity with other isolates of ACMV was named ACMV-[TZ]. It represents the first ACMV isolate from Tanzania to be sequenced. The molecular variability of CMGs was also evaluated using partial B component nucleotide sequences of 13 EACMV isolates from Tanzania. Using the sequences of all CMGs currently available, we have shown the presence of a number of putative recombination fragments that are more prominent in all components of EACMV than in ACMV. This new knowledge about the molecular CMG diversity in East Africa, and in Tanzania in particular, has led us to hypothesize about the probable importance of this part of Africa as a source of diversity and evolutionary change both during the early stages of the relationship between CMGs and cassava and in more recent times. The existence of multiple CMG isolates with high DNA genome diversity in Tanzania and the molecular forces behind this diversity pose a threat to cassava production throughout the African continent.
\end{abstract}




\section{Background}

Geminiviruses are a large family of plant viruses with circular, single-stranded DNA (ssDNA) genomes packaged within geminate particles. The family Geminiviridae is divided into four genera (Mastrevirus, Curtovirus, Topocuvirus, and Begomovirus) according to their genome organizations and biological properties [1,2]. Members of the genus Begomovirus have caused significant yield losses in many crops worldwide [3] and are transmitted by whiteflies (Bemisia tabaci) to dicotyledonous plants. The genome of cassava mosaic geminiviruses (CMGs) in the genus Begomovirus consists of two DNA molecules, DNA$A$ and DNA-B, each of about $2.8 \mathrm{kbp} \mathrm{[1],} \mathrm{which} \mathrm{are}$ responsible for different functions in the infection process. DNA-A encodes genes responsible for viral replication [AC1 (Rep), and AC3 (Ren)], regulation of gene expression [AC2 (Trap)] and particle encapsidation [AV1 (CP)]. DNA-B encodes for two proteins, BC1 (MP) and BV1 (NSP) involved in cell-to-cell movement within the plant, host range and symptom modulation [1]. CMGs have been reported from many cassava-growing countries in Africa and the cassava mosaic disease (CMD) induced by them constitutes a formidable threat to cassava production [4].

Representatives of six distinct CMG species have been found to infect cassava in Africa: African cassava mosaic virus (ACMV), East African cassava mosaic virus (EACMV), East African cassava mosaic Cameroon virus (EACMCV), East African cassava mosaic Malawi virus (EACMMV), East African cassava mosaic Zanzibar virus (EACMZV) and South African cassava mosaic virus (SACMV) [5]. Recent studies have uncovered much variation in CMGs including evidence that certain CMGs, when present in mixtures, employ pseudo-recombination or reassortment strategies and recombination at certain hot spots such as the origin of replication [6-10] resulting in the emergence of 'new' viruses with altered virulence. For instance, an ACMVEACMV recombinant component A, designated EACMVUG2, and a pseudo-recombinant component B, designated EACMV-UG3 [10], have been implicated in the pandemic of severe CMD currently devastating cassava in much of east and central Africa [4]. In 1997, only ACMV and EACMV were known to occur in Tanzania with the former occurring only in the western part of the country [11]. The discovery of EACMZV on the island of Zanzibar [12] together with the recent spread into Tanzania of the EACMV-UG2 associated pandemic of severe CMD [4,13] has aggravated the CMD situation. Consequently, there is much to be learned about the identity, distribution, molecular variability, and the threat that these emerging geminiviruses pose to cassava production in Tanzania and more generally in Africa.
In 1997, the first recombination between two species of geminiviruses was recorded $[7,8]$. This mechanism is now known to be widely used by all geminiviruses and is probably the most important molecular mechanism for generating genetic changes that allow novel geminiviruses to exploit new ecological niches $[2,14]$.

This paper describes the results of a molecular study of the sequences of CMGs collected from the major cassavagrowing areas of Tanzania in an effort towards identifying, determining molecular variability and mapping the distribution of CMGs. In addition, because East Africa seems to be unusually rich in virus biodiversity and because the most recent cassava pandemic was first reported in East Africa, we investigated the extent of inter-CMG recombinations and examined their role in the evolution of CMGs in Africa.

\section{Results}

\section{Assessment of CMD symptoms}

Over $80 \%$ of the cassava plants in the fields showed severe CMD symptoms with cassava in the Lake Victoria basin expressing the most severe symptoms followed by that from the southern regions. Symptoms of infected cassava samples collected in the field were reproduced in controlled conditions to examine symptom variability. From a total of 35 selected cuttings planted, 25 (71\%) were successfully established in the growth chamber. In all cases, regardless of the cultivar, symptoms expressed in the field, whether moderate or severe, were reproduced in the growth chamber and plants did not recover from the disease even 12 months after planting (Fig. 2). Likewise, plants that displayed moderate symptoms in the field showed a similar symptom in the growth chamber as was the case for plants singly-infected with ACMV-[TZ] (Fig. 2).

\section{Detection of viral genomic components}

PCR amplification products $(2.7-2.8 \mathrm{kbp})$ were observed for all the CMG isolates tested using primer UNIF/UNIR (Table 1) designed to amplify near-full-length DNA-A of CMGs. Bands were not observed with the negative control (nucleic acid preparation from healthy cassava plants). Similarly, a specific ( $2.7 \mathrm{kbp}$ ) product was observed when using abutting primers TZ1B-F/R designed from a $560 \mathrm{bp}$ DNA-B fragment initially PCR-amplified using universal primers EAB555/F and EAB555R for general detection of CMGs DNA-B. DNA-B partial fragments (544-560 kbp) were consistently amplified by PCR using primers EAB555-F and EAB555-R (Table 1) for all the CMD-diseased samples previously shown to contain EACMV isolates collected from major cassava-growing areas in Tanzania [13]. 

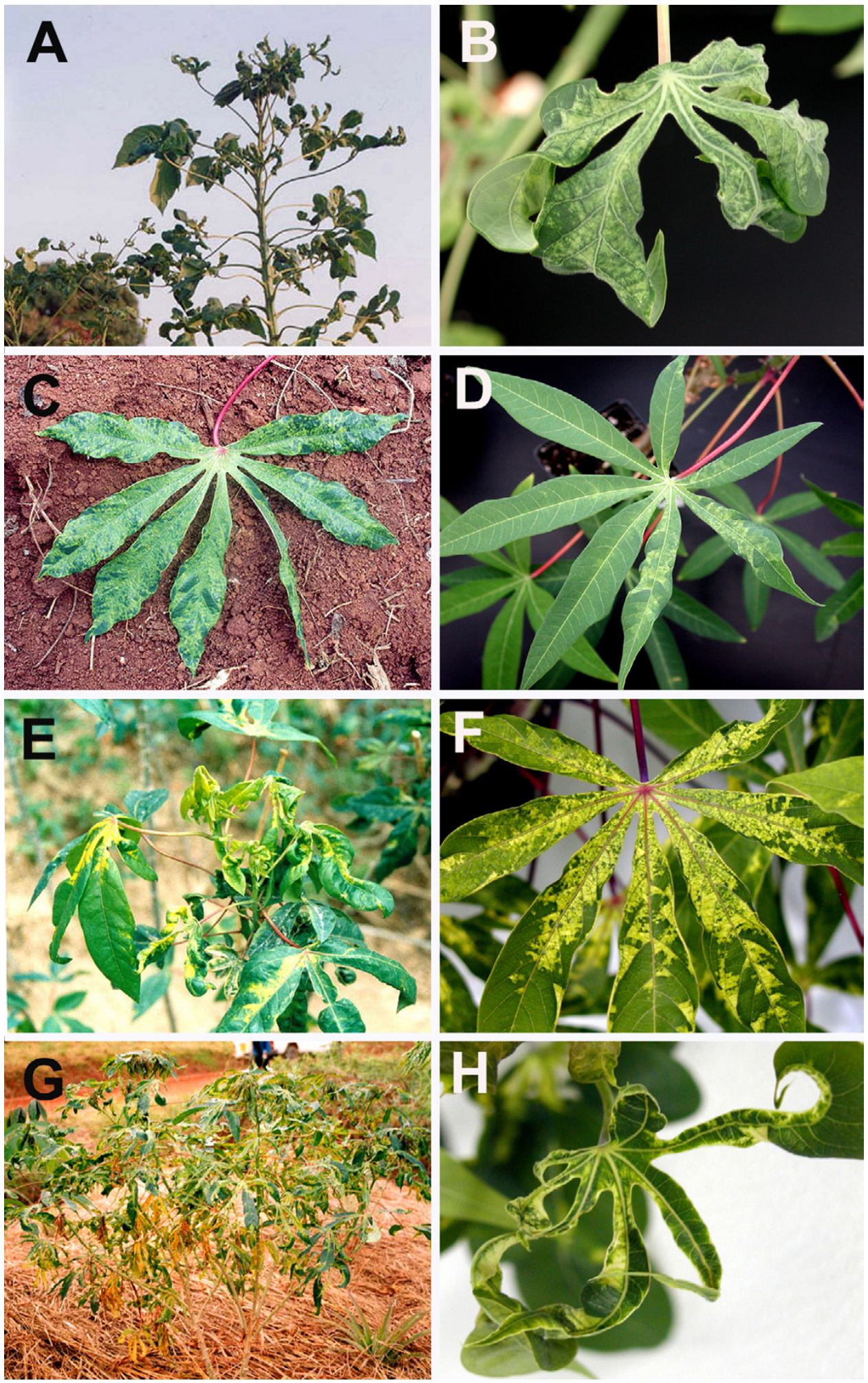

Figure 2

CMD symptoms on naturally infected cassava plants (A, C, E and $G$ ) in the field with their corresponding plants raised from field-collected cuttings maintained in the growth chamber $(B, D, F$ and $H)$. Only plants containing single virus infection are shown. Plants $A$ and $B$ contained a single infection of EACMV-[KE/TZM], $C$ and $D$ contained ACMV-[TZ], E and $F$ were infected by EACMCV-[TZI] and $\mathrm{G}$ and $\mathrm{H}$ by EACMV-UG2 [TZI0]. 
Table I: List of the oligonucleotide primers used in this study for amplification of cassava mosaic geminiviruses from Tanzania ( ${ }^{\mathrm{a} n f l}=$ near-full length, ps = partial sequence)

\begin{tabular}{|c|c|c|c|}
\hline Primer name & Nucleotide sequence $\left(5^{\prime} \rightarrow 3^{\prime}\right)$ & Begomovirus isolate & DNA component \\
\hline UGT-F & $\begin{array}{l}\text { TCGTCTAGAACAATACTGATC } \\
\text { GGTCTCC }\end{array}$ & EACMV-KE-[TZT] & DNA-A fla \\
\hline UGT-R & $\begin{array}{l}\text { CGGTCTAGAAGGTGATAGCC } \\
\text { GAACCGGGA }\end{array}$ & EACMV-KE-[TZT] & DNA-A fl \\
\hline $3 \mathrm{~T}-\mathrm{F}$ & $\begin{array}{l}\text { ACGTCTAGAACAATACTGATC } \\
\text { GGTCTC }\end{array}$ & EACMV-TZ-[YV] & DNA-A fl \\
\hline $3 T-R$ & $\begin{array}{l}\text { GTGCTCTAGAAGGTGATAGC } \\
\text { CGAACCGGGA }\end{array}$ & EACMV-TZ-[YV] & DNA-A fl \\
\hline TZIB-F & $\begin{array}{l}\text { GCGCGGAATCACTTGTGAAG } \\
\text { CAGTCGT }\end{array}$ & EACMCV-[TZI] & DNA-B fl \\
\hline TZIB-R & $\begin{array}{l}\text { GCCGGGATTCGGTGAGTGGT } \\
\text { TTACATCAC }\end{array}$ & EACMCV-[TZI] & DNA-B fl \\
\hline $\mathrm{EAB} 555 / \mathrm{F}$ & $\begin{array}{l}\text { TACATCGGCCTTTGAGTCGC } \\
\text { ATGG }\end{array}$ & CMGs & $\mathrm{BCl} / \mathrm{CR}$ \\
\hline EAB555/R & $\begin{array}{l}\text { CTTATTAACGCCTATATAAAC } \\
\text { ACC }\end{array}$ & CMGs & $\mathrm{BCI} / \mathrm{CR}$ \\
\hline UNI/F & $\begin{array}{l}\text { KSGGGTCGACGTCATCAATGA } \\
\text { CGTTRTAC }\end{array}$ & CMGs & DNA-A nfl \\
\hline UNI/R & $\begin{array}{l}\text { AARGAATTCATKGGGGCCCA } \\
\text { RARRGACTGGC }\end{array}$ & CMGs & DNA-A nfl \\
\hline AT-F & GTGACGAAGATTGCATTCT & ACMV-[TZ] & DNA-A ps \\
\hline AT-R & AATAGTATTGTCATAGAAG & ACMV-[TZ] & DNA-A ps \\
\hline ATZI-F & TAAGAAGATGGTGGGAATCC & EACMCV-[TZI] & DNA-A ps \\
\hline ATZ-R & CGATCAGTATTGTTCTGGAAC & EACMCV-[TZI] & DNA-A ps \\
\hline TZ7-F & TGGTGGGAATCCCACCTT & EACMCV-[TZ7] & DNA-A ps \\
\hline TZ7-R & GTATTGTTATGGAAGGTGATA & EACMCV-[TZ7] & DNA-A ps \\
\hline TZM-F & TATATGATGATGTTGGTC & EACMV-UG2Svr-[TZI0] & DNA-A ps \\
\hline TZIO-R & TAGAAGGTGATAGCCGTA & EACMV-UG2Svr-[TZI0] & DNA-A ps \\
\hline TZM-F & TATATGATGATGTTGGTC & EACMV-KE-[TZM] & DNA-A ps \\
\hline TZM-R & TAGAAGGTGATAGCCGAAC & EACMV-KE-TZM] & DNA-A ps \\
\hline
\end{tabular}

\section{Complete nucleotide sequence characteristics of CMGs} from Tanzania

The complete DNA-A sequences of seven representative CMGs from the major cassava-growing areas were determined from the representative isolates selected and grown in the growth chambers. An ACMV isolate from Tanzania (ACMV-[TZ]) was shown to be most closely related to ACMV-UGMld from Uganda with a sequence identity of $97 \%$. Its DNA-A nucleotide ( $\mathrm{nt}$ ) sequence was established to be $2779 \mathrm{nts}$ in length. It has a high overall sequence identity (>90\%) with all other published sequences of ACMV isolates (Table 2) with which it clusters in the phylogenetic tree presented in Figure 3. The DNA-A sequence organization was typical of a begomovirus, with two open reading frames (ORFs) (AV2 and AV1) in the virion-sense DNA, and four ORFs (AC1 to AC4) in the complementary sense, separated by an intergenic region (IR). Complete nt sequences of the DNA-A genomes of the different Tanzanian EACMV and ACMV isolates were compared with published sequences (Table 2).

Two isolates, TZ1 and TZ7, with 2798 and 2799 nts respectively, collected from Mbinga district in southwest- ern Tanzania, were most closely related to isolates of the species East African cassava mosaic Cameroon virus from Cameroon and Ivory Coast, West Africa, (EACMCV-[CM], -[CI]), with $89-90 \%$ nt sequence identity. They are clearly isolates of EACMCV and we have named them EACMCV[TZ1] and EACMCV-[TZ7] to indicate that they were from Tanzania and to distinguish them from the original EAC$\mathrm{MCV}-[\mathrm{CM}]$ isolate from Cameroon. The two isolates were also virtually identical to one another having high overall DNA sequence conservation (93\% nt sequence identity). Phylogenetic analysis of the DNA-A nt sequences grouped EACMCV-[TZ1] and EACMCV-[TZ7] in the same cluster with EACMCV-[CM] and EACMCV-[CI] (Fig. 3). The complete nt sequence of the EACMCV-[TZ1] DNA-B component was determined to be 2726 nts long and had the highest sequence identity (85\%) with EACMCV-[CM] DNA-B with which it is grouped in the phylogenetic tree (Fig. 4). It had less than $72 \%$ homology with DNA-Bs of other EACMV isolates from East Africa.

The complete DNA-A genome of CMG isolates from Yombo Vituka (YV) and Tanga (TZT) in the coastal area of Tanzania were determined to be 2800 and 2801 nts long 
Table 2: Nucleotide sequence identities (percentages) of the DNA-A full-length of cassava mosaic geminiviruses from Tanzania and other geminiviruses from Africa and the Indian sub-continent. Values above $\mathbf{8 9 \%}$ are in bold and names of isolates from Tanzania are in bold.

\begin{tabular}{|c|c|c|c|c|c|c|c|}
\hline Virus Isolate & $\begin{array}{c}\text { ACMV- } \\
\text { [TZ] }\end{array}$ & $\begin{array}{c}\text { EACMCV- } \\
\text { [TZI] }\end{array}$ & $\begin{array}{c}\text { EACMCV- } \\
\text { [TZ7] }\end{array}$ & $\begin{array}{l}\text { EACMV- } \\
\text { [KE/TZT] }\end{array}$ & $\begin{array}{l}\text { EACMV- } \\
\text { [KE/TZM] }\end{array}$ & $\begin{array}{l}\text { EACMV- } \\
\text { [TZ/YV] }\end{array}$ & $\begin{array}{c}\text { EACMV-UG2 } \\
\text { [TZIO] }\end{array}$ \\
\hline ACMV-[CM] & 95 & 68 & 68 & 70 & 70 & 69 & 73 \\
\hline ACMV-[CM/DO2] & 95 & 68 & 68 & 70 & 70 & 69 & 73 \\
\hline ACMV-[IC] & 96 & 68 & 68 & 70 & 71 & 70 & 73 \\
\hline ACMV-[KE] & 96 & 68 & 68 & 70 & 70 & 70 & 73 \\
\hline ACMV-[NG] & 95 & 68 & 68 & 70 & 70 & 70 & 73 \\
\hline ACMV-[NG/Ogo] & 96 & 68 & 68 & 70 & 70 & 70 & 73 \\
\hline ACMV-ÜGMId & 97 & 68 & 68 & 70 & 71 & 70 & 73 \\
\hline ACMV-UGSVr & 96 & 68 & 68 & 70 & 71 & 70 & 74 \\
\hline ACMV-[TZ] & - & 68 & 68 & 70 & 70 & 70 & 73 \\
\hline EACMCV-[CM] & 67 & 90 & 89 & 87 & 87 & 85 & 84 \\
\hline EACMCV-[Cl] & 67 & 90 & 90 & 88 & 87 & 86 & 85 \\
\hline EACMCV-[TZI] & 68 & - & 96 & 88 & 88 & 87 & 85 \\
\hline EACMCV-[TZ7] & 68 & 96 & - & 88 & 88 & 87 & 85 \\
\hline EACMMV-[K] & 71 & 81 & 81 & 87 & 88 & 86 & 87 \\
\hline EACMMV-[MH] & 71 & 81 & 81 & 87 & 88 & 86 & 88 \\
\hline EACMV-[KE/K2B] & 70 & 88 & 88 & 97 & 96 & 94 & 92 \\
\hline EACMV-[TZ] & 69 & 88 & 88 & 94 & 94 & 95 & 91 \\
\hline EACMV-[KE/TZT] & 70 & 88 & 88 & - & 95 & 93 & 92 \\
\hline EACMV-[KE/TZM] & 70 & 88 & 88 & 96 & - & 94 & 92 \\
\hline EACMV-[TZ/YV] & 70 & 87 & 87 & 94 & 93 & - & 90 \\
\hline EACMV-UG2 & 73 & 85 & 85 & 92 & 92 & 92 & 98 \\
\hline EACMV-UG2Mld & 73 & 86 & 86 & 93 & 92 & 92 & 99 \\
\hline EACMV-UG2Svr & 73 & 86 & 86 & 93 & 92 & 92 & 99 \\
\hline EACMV-UG2 [TZIO] & 73 & 85 & 85 & 92 & 92 & 91 & - \\
\hline EACMZV-[ZB] & 72 & 80 & 80 & 86 & 86 & 86 & 83 \\
\hline EACMZV-[KE/Kil] & 72 & 79 & 79 & 86 & 86 & 85 & 83 \\
\hline SACMV-[ZA] & 74 & 73 & 73 & 80 & 80 & 79 & 80 \\
\hline SACMV-[ZW] & 74 & 73 & 73 & 80 & 80 & 80 & 80 \\
\hline SACMV-[MI2] & 74 & 73 & 73 & 80 & 80 & 80 & 80 \\
\hline SLCMV-[Col] & 73 & 67 & 67 & 67 & 67 & 67 & 67 \\
\hline TGMV-[Com] & 58 & 59 & 59 & 59 & 59 & 59 & 59 \\
\hline
\end{tabular}

respectively. Isolate YV showed high (95\%) overall nt sequence identity with previously characterized EACMV[TZ] and is therefore named EACMV-[TZ/YV] in the Dares-Salaam region. It also had high overall sequence identity (87-96\%) with other Tanzanian EACMV isolates characterized in this study (Table 2). Phylogenetic analysis of the complete nt sequence of EACMV-[TZ/YV] grouped it with its closest relative, EACMV-TZ (Fig. 3). CMG isolate TZT had high sequence identity (96.5\%) with EACMV-[KE/K2B] from Kenya and is named EACMV-[KE/TZT]. Similarly, another CMG isolate (TZM) from the Mara region in the Lake Victoria zone was found to have high overall sequence identity (96\%) with EACMV-[KE/K2B] and we have named it EACMV-[KE/ TZM]. This isolate, $2805 \mathrm{nts}$ in length, together with EACMV-[KE/TZT], clustered with EACMV-[KE/K2B] in the phylogenetic tree (Fig. 3). Another isolate from Kagera region in northwestern Tanzania (TZ10) showed very high overall DNA-A nt sequence identity (98.8\%) with the published sequence of EACMV-UG2Svr. Its complete DNA-A nt sequence was 2804 nts long and it was named EACMV-UG2 [TZ10]. 
Table 3: CP gene nucleotide sequence identity (\%) of cassava mosaic geminiviruses from Tanzania and other published CMG CP sequences. Values above $\mathbf{8 9 \%}$ are in bold and names of isolates from Tanzania are in blue.

\begin{tabular}{|c|c|c|c|c|c|c|c|}
\hline Virus Isolate & $\begin{array}{c}\text { ACMV- } \\
\text { [TZ] }\end{array}$ & $\begin{array}{c}\text { EACMCV- } \\
\text { [TZI] }\end{array}$ & $\begin{array}{c}\text { EACMCV- } \\
\text { [TZ7] }\end{array}$ & $\begin{array}{l}\text { EACMV- } \\
\text { [KE/TZT] }\end{array}$ & $\begin{array}{l}\text { EACM- } \\
\text { [KE/TZM] }\end{array}$ & $\begin{array}{l}\text { EACMV- } \\
\text { [TZ/YV] }\end{array}$ & $\begin{array}{c}\text { EACMV-UG2 } \\
\text { [TZ10] }\end{array}$ \\
\hline ACMV-[CM] & 97 & 77 & 77 & 78 & 79 & 77 & 90 \\
\hline ACMV-[Cl] & 96 & 77 & 78 & 78 & 79 & 77 & 90 \\
\hline ACMV-[KE] & 97 & 76 & 76 & 77 & 78 & 76 & 90 \\
\hline ACMV-[NG] & 96 & 77 & 77 & 78 & 78 & 77 & 90 \\
\hline ACMV-UGMId & 97 & 76 & 77 & 78 & 78 & 76 & 90 \\
\hline ACMV-[TZ] & - & 77 & 77 & 78 & 78 & 77 & 89 \\
\hline EACMCV-[CM] & 77 & 94 & 94 & 95 & 96 & 93 & 84 \\
\hline EACMCV-[TZI] & 77 & - & 97 & 95 & 96 & 94 & 84 \\
\hline EACMCV-[TZ7] & 77 & 97 & - & 95 & 97 & 95 & 84 \\
\hline EACMMV-[K] & 77 & 80 & 80 & 80 & 80 & 80 & 79 \\
\hline EACMMV-[MH] & 77 & 79 & 80 & 80 & 80 & 80 & 79 \\
\hline EACMV-[KE/K2B] & 77 & 95 & 96 & 96 & 97 & 96 & 84 \\
\hline EACMV-TZ & 77 & 95 & 95 & 96 & 97 & 96 & 85 \\
\hline EACMV-[KE/TZT] & 78 & 95 & 95 & - & 97 & 95 & 85 \\
\hline EACMV-[KE/TZM] & 78 & 96 & 97 & 97 & - & 97 & 84 \\
\hline EACMV-[TZ/YV] & 77 & 94 & 95 & 95 & 96 & - & 84 \\
\hline EACMV-UG2 & 90 & 84 & 84 & 85 & 85 & 84 & 99 \\
\hline EACMV-UG2MId & 89 & 84 & 84 & 85 & 85 & 84 & 98 \\
\hline EACMV-UG2Svr & 90 & 84 & 84 & 85 & 85 & 84 & 99 \\
\hline EACMV-UG2 [TZI0] & 89 & 84 & 84 & 85 & 84 & 84 & - \\
\hline EACMZV-[ZB] & 78 & 96 & 96 & 97 & 97 & 96 & 85 \\
\hline SACMV-[ZA] & 77 & 78 & 79 & 80 & 79 & 79 & 73 \\
\hline ICMV-[Tri] & 74 & 73 & 73 & 74 & 74 & 73 & 64 \\
\hline TGMV-[Com] & 63 & 65 & 65 & 64 & 64 & 65 & 78 \\
\hline
\end{tabular}

\section{Determination of genetic diversity of EACMV DNA-B using partial sequences}

The diversity of different CMG isolates was analyzed using a partial DNA-B genomic region spanning the N-terminal region of $\mathrm{BC} 1$ to the intergenic region (IR). Identities of these sequences with those of the corresponding DNA-B genomic regions of other CMGs in GenBank were determined. Generally, the EACMV isolates showed little genetic divergence amongst one another and isolates collected from the same area displayed high nt sequence identity. Isolates TZB1 and TZB7 from the southern part of Tanzania shared the highest $(98 \%)$ nt sequence identity followed by TZB3 and TZB8 (94\%) as well as TZB and TZB10, all from the east coast area. TZB2 was most closely related to and shared 91\% sequence identity with TZB4, both collected from the coastal area. None of the isolates from the south or coastal areas shared $>85 \%$ nt sequence identity with those from the Lake Victoria basin (TZB9 and TZB12).

The phylogenetic tree generated from a multiple alignment of 13 EACMV isolates with selected bipartite begomovirus sequences and EACMCV-[TZ1] B component is shown in Figure 4. All 13 Tanzanian isolates studied clustered with the reference EACMVs, with TZB6 being most closely related to Ugandan isolates (EACMV-UG3Svr, EACMV-UG3Mld and EACMV-UG1) (Fig. 4) sharing 97\% nt sequence identity. Four isolates (TZB3, TZB5, TZB8 and TZB9) formed a closely related group, with TZB8 and TZB9 being the most closely related. Isolates TZMB, TZB5 and TZB11 each grouped separately. None of the EACMV isolates grouped with ICMV and SLCMV from the Indian subcontinent (Fig. 4). 


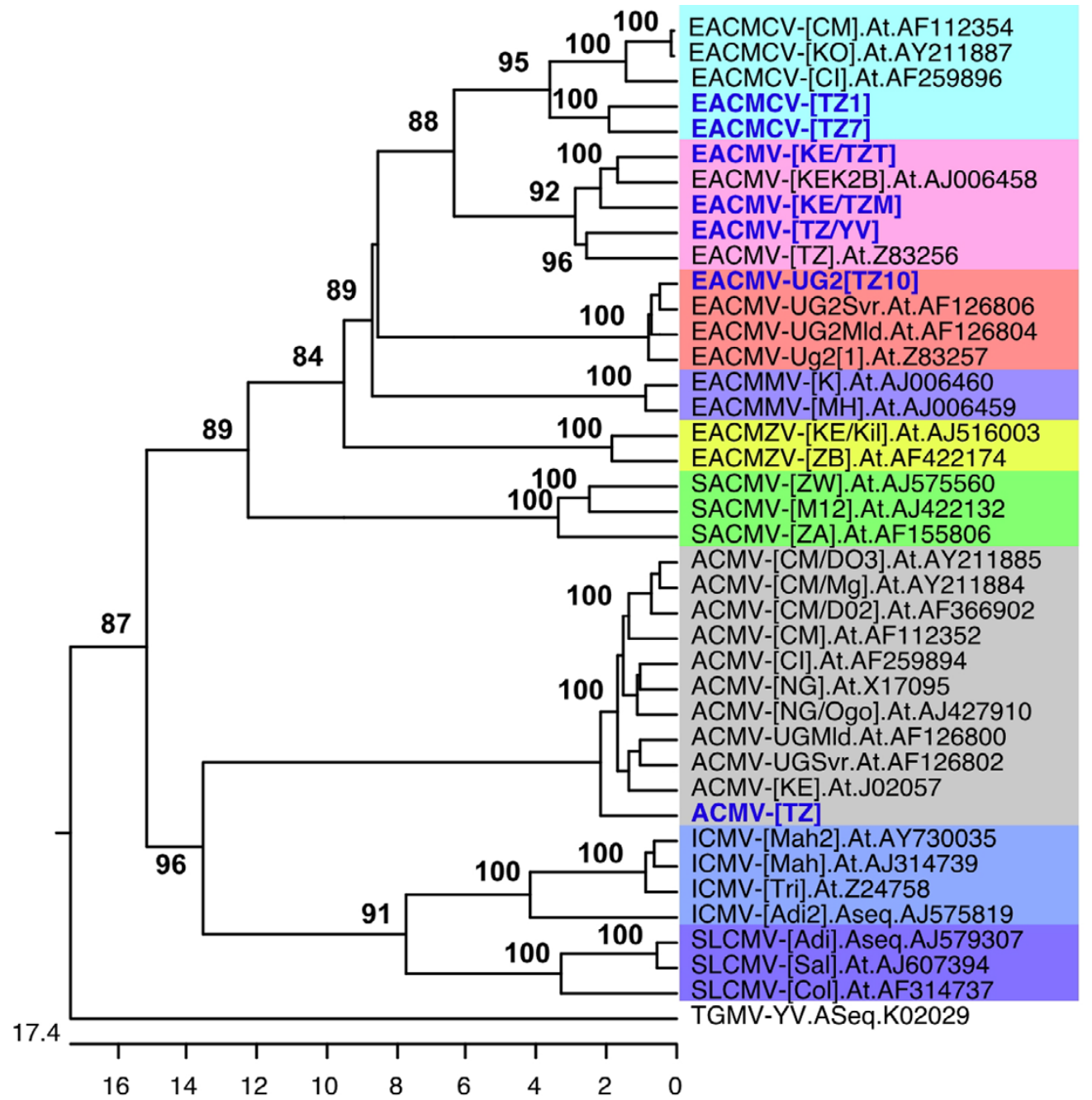

\section{EACMCV}

\section{EACMV}

EACMV-UG

EACMMV

EACMZV

SACMV

\author{
ACMV
}

ICMV

\section{SLCMV}

Figure 3

Phylogenetic tree (1000 boot strap replications) showing the DNA-A complete nucleotide sequence relationships between the seven Tanzanian cassava mosaic geminivirus isolates (in blue) and other cassava mosaic geminiviruses. Tomato golden mosaic virus (TGMV-YV) (K02029) was used as the out group. Abbreviations and accession numbers are: ACMV-[Cl], African cassava mosaic virus-[Côte d'Ivoire] (AF259894); ACMV-[NG/Ogo], African cassava mosaic virus-[Nigeria-Ogo] (AJ4279l0); ACMV[CM/D02], African cassava mosaic virus-[Cameroon D02] (AF366902); ACMV-[CM/D03], African cassava mosaic virus-[Cameroon D03] (AY2I I885); ACMV-[CM/Mg], African cassava mosaic virus-[Cameroon Mg] (AY2I I884); ACMV-[CM], African cassava mosaic virus-[Cameroon] (AFI I2352); ACMV-[KE], African cassava mosaic virus-[Kenya] (J02057); ACMV-[NG], African cassava mosaic virus-[Nigeria] (XI7095); ACMV-UGMId, African cassava mosaic virus-Uganda mild (AFI26800); ACMV-UGSvr, African cassava mosaic virus-Uganda severe (AFI26802); EACMCV-[CM/KO], East African cassava mosaic Cameroon virus-[Cameroon KO] (AY2I I 887); EACMCV-[CM], East African cassava mosaic Cameroon virus-[Cameroon] (AFI I 2354); EACMCV-[CI], East African cassava mosaic Cameroon virus-[Côte d'Ivoire] (AF259896); EACMMV-[K], East African cassava mosaic Malawi virus[K] (AJ006460); EACMMV-[MH], East African cassava mosaic Malawi virus-[MH] (AJ006459); EACMV-[KE/k2B], East African cassava mosaic virus [Kenya-K2B] (AJ006458); EACMV-[TZ], East African cassava mosaic virus-[Tanzania] (Z53256); EACMVUG2[2], East African cassava mosaic virus-Uganda2[2] (Z83257); EACMV-UG2Mld, East African cassava mosaic virus-Uganda2 mild (AFI 26804); EACMV-UG2Svr, East African cassava mosaic virus-Uganda2 severe (AFI26806); EACMZV-[KE/Kil], East African cassava mosaic Zanzibar virus-[Kenya -Kil] (AJ5I6003); EACMZV-[ZB], East African cassava mosaic Zanzibar Virus - [Zanzibar] (AF422 I 74); ICMV-[Adi2], Indian cassava mosaic virus - [Adivaram 2] (AJ5758I9); ICMV-[Mah], Indian cassava mosaic virus [Maharashstra] (AJ3 I4739); ICMV-[Mah2], Indian cassava mosaic virus - [Maharashstra 2] (AY730035); ICMV-[Tri], Indian cassava mosaic virus - [Trivandrum] (Z24758); SACMV-[MI2], South African cassava mosaic virus-[Madagascar MI2] (AJ422I32); SACMV-[ZA], South African cassava mosaic virus - [South Africa] (AFI55806); SACMV-[ZW], South African cassava mosaic virus [Zimbabwe] (AJ575560); SLCMV-[Adi], Sri-Lankan cassava mosaic virus-[Adivaram] (AJ579307); SLCMV-[Col], Sri-Lankan cassava mosaic virus-[Colombo] (AF3 I4737); SLCMV-[Sal], Sri-Lankan cassava mosaic virus-[Salem] (AJ607394). 


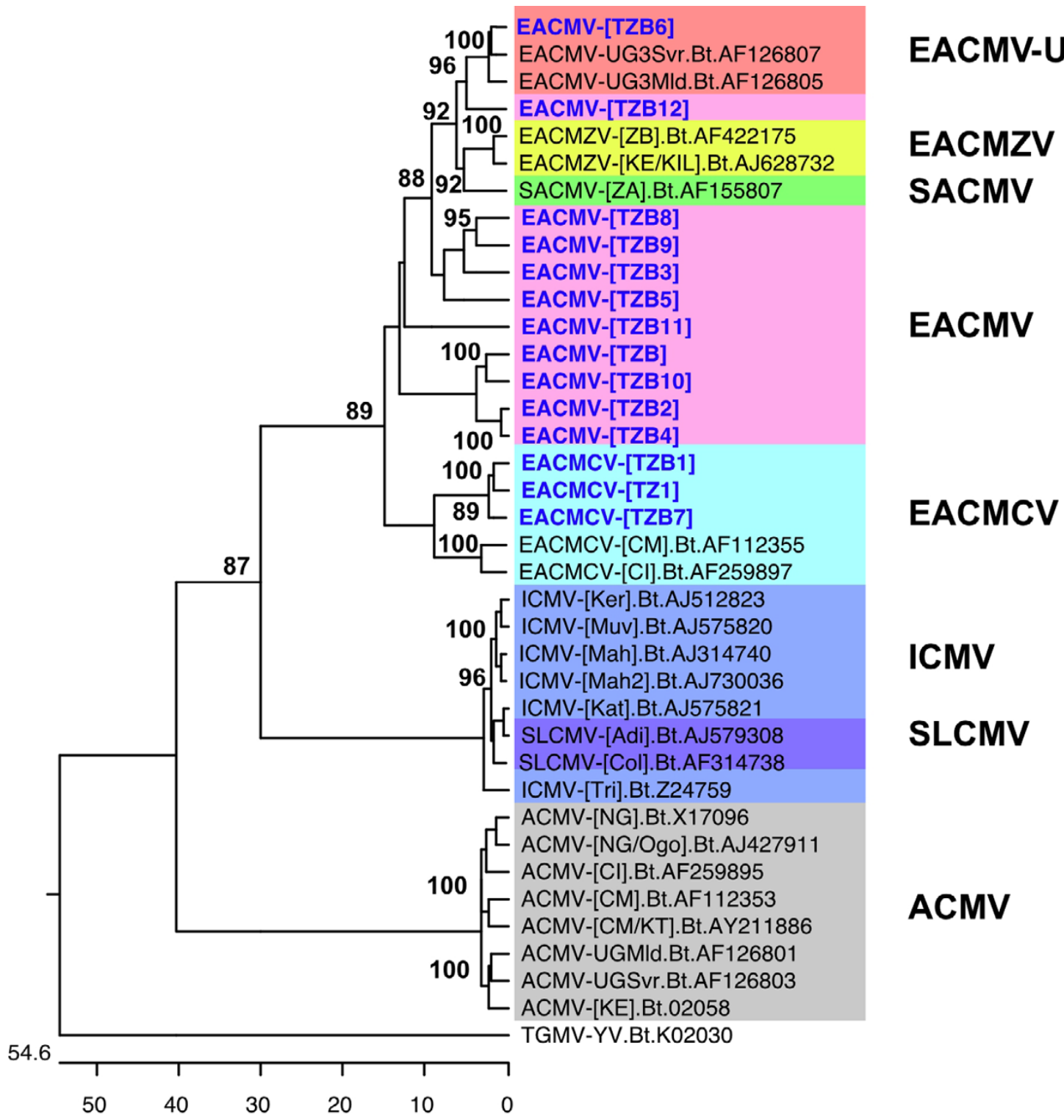

Figure 4

Phylogenetic tree ( 1000 bootstrap replications) obtained from comparison of the complete nucleotide sequence of EACMCV[TZI] DNA-B, partial B component sequences from Tanzania (TZBX) and available cassava mosaic geminivirus DNA-B component sequences. Tomato golden mosaic virus (TGMV-YV) (K02030) was used as the out-group. Abbreviations and accession numbers are: ACMV-[Cl], African cassava mosaic virus-[Côte d'Ivoire] (AF259895); ACMV-[NG/Ogo], African cassava mosaic virus-[Nigeria-Ogo] (AJ4279II); ACMV-[CM/KT], African cassava mosaic virus-[Cameroon KT] (AY2I I886); ACMV-[CM], African cassava mosaic virus-[Cameroon] (AFI I 2353); ACMV-[KE], African cassava mosaic virus-[Kenya] (J02058); ACMV-[NG], African cassava mosaic virus-[Nigeria] (XI7096); ACMV-UGMld, African cassava mosaic virus-Uganda mild (AFI2680I); ACMVUGSvr, African cassava mosaic virus-Uganda severe (AFI 26803); EACMCV-[CM], East African cassava mosaic Cameroon virus[Cameroon] (AFI I2355); EACMCV-[Cl], East African cassava mosaic Cameroon virus-[Côte d'Ivoire] (AF259897); EACMVUG3MId, East African cassava mosaic virus-Uganda3 mild (AFI26805); EACMV-UG3Svr, East African cassava mosaic virus-Uganda3 severe (AFI26807); EACMZV-[KE/Kil], East African cassava mosaic Zanzibar virus-[Kenya -Kil] (AJ628732); EACMZV-[ZB], East African cassava mosaic Zanzibar Virus - [Zanzibar] (AF422I75); ICMV-[Kat], Indian cassava mosaic virus - [Kattukuda] (AJ57582 I); ICMV-[Ker], Indian cassava mosaic virus - [Kerala] (AJ575823); ICMV-[Mah], Indian cassava mosaic virus - [Maharashstra] (AJ3 I4740); ICMV-[Mah2], Indian cassava mosaic virus - [Maharashstra 2] (AY730036); ICMV-[Tri], Indian cassava mosaic virus - [Trivandrum] (Z24759); SACMV-[ZA], South African cassava mosaic virus - [South Africa] (AFI55807); SLCMV[Adi], Sri-Lankan cassava mosaic virus-[Adivaram] (AJ579308); SLCMV-[Col], Sri-Lankan cassava mosaic virus-[Colombo] (AF3|4738). 


\section{Capsid protein (CP) gene sequence analysis and comparison with selected viruses}

The CP gene sequences of the seven CMGs identified in our study were compared to published sequences (Table 3). ACMV-[TZ] shared the highest nt sequence identity (97.4\%) with ACMV-UGMld from Uganda followed by $\mathrm{ACMV}-[\mathrm{CM}]$, an isolate from Cameroon. The lowest sequence identity (63.2\%) was recorded with TGMV-YV (Table 3), an American begomovirus. Both EACMCV[TZ1] and EACMCV-[TZ7] were more than 92\% identical to EACMCV-[CM], but they also had very high nt sequence identity (95\%) with EACMZV from Zanzibar and EACMV-[KE/K2B] (Table 3) and 96\% between each other. Interestingly, EACMV-[KE/TZT] and EACMV-[KE/ TZM] collectively shared high (97\%) identity with EACMZV followed by EACMV-[KE/K2B](96-97\%) and up to $96 \%$ between each other. Furthermore the EACMV[TZ/YV] CP gene sequence showed very high identity with EACMV-[TZ] (96\%) and EACMZV (96\%) followed by EACMV-[KE/K2B](95\%) (Table 3). The EACMV-UG2 [TZ10] sequence shared a very high nt sequence identity (99\%) with EACMV-UG2Svr from Uganda and high identity (98-99\%) with other Ugandan isolates of EACMV. As expected, EACMV-UG2 [TZ10] shared 90\% sequence homology with ACMV (Table 3), suggesting it contained the recombination at the $\mathrm{CP}$ gene level previously reported $[7,8]$ for EACMV-UG2.

A phylogenetic analysis of the CP of Tanzanian CMGs yielded a tree (Fig. 5) that was in agreement with the relationship predicted by pairwise sequence comparison (Table 4). ACMV-[TZ] clustered with other ACMV isolates while EACMV-UG2 [TZ10] grouped with Ugandan isolates of EACMV. EACMCV-[TZ1], EACMCV-[TZ7], EACMV-[TZ/YV], and the two viruses, EACMV-[KE/TZT] and EACMV-[KE/TZM] clustered with other EACMV isolates from either Cameroon or Kenya. No CMG isolate identified in this study clustered with EACMMV from Malawi, SACMV from South Africa, ICMV, or SLCMV from the Indian sub-continent when their CP gene nucleotide sequences were compared (Fig. 5).

\section{The common regions (CRs) of the Tanzanian CMGs}

The conserved nonanucleotide in the hairpin-loop, TAATATTAC, that is characteristic of the members of the family Geminiviridae and the AC1 TATA box, were identified in the CR sequences of all the Tanzanian CMGs (Fig. 6a,6b). The CR of ACMV-[TZ] was $170 \mathrm{nts}$ long while those for EACMV were between 152 and 157 nts in length. When the CR sequence of ACMV-[TZ] was compared and aligned to the published CR sequences of other cassavainfecting ACMV isolates from Africa (Fig. 6a), it was apparent that ACMV-[TZ] was virtually identical to all ACMV isolates. The repeated motif upstream the TATA box for all the published ACMV isolates was AATTGGAGA
(Fig. 6a). The motif for ACMV-[TZ], AATTGGAGA, was identical. Figure $6 \mathrm{~b}$ presents the alignment of the CRs of the Tanzanian EACMVs with sequences of all published EACMVs. It was found that all the isolates contained the various features characteristic of begomoviruses. The putative Rep-binding sequences (iterons) were GGTGGAATGGGGG for all the Tanzanian isolates except EACMV-[TZ/YV] that had different iterons (GGGGGAACGGGGG) and a total of 23 mismatches in the entire CR. It is worth noting that although the genomes of the two isolates of EACMZV are EACMVbased, their CRs are more similar to ACMV than to EACMV and the iteron is AATTGGAGA.

The comparisons of the nt sequences of the CRs of Tanzanian CMGs with other CMGs revealed high sequence identity (>90\%) of ACMV-[TZ] to published sequences of other ACMV isolates and low identity (61-62\%) to EACMV species. Similarly, all the Tanzanian EACMV isolates were related with sequence identities of $83-97 \%$ between CRs of the DNA-A and DNA-B. The CR of EACMV-[TZ/YV] showed a relatively low sequence identity to other isolates. EACMCV-[TZ1] (DNA-A and -B) and the EACMCV-[TZ7] showed high nt sequence identity to EACMCV (Table 4).

\section{Geographical distribution of the CMGs in Tanzania}

The representative isolates sequenced here have been chosen because they represent a range of different RFLP patterns found during a large set of 485 samples collected throughout Tanzania [13]. However, the selection of isolates to sequence was based on the differences in RFLP patterns and not on their frequency of appearance in the country. Figure 7 shows the different locations of these samples represented by the isolates sequenced here. The EACMCV-[TZ1] was the most widespread, found in 50 samples located mainly in the southern part of Tanzania in the Mbinga District of Ruvuma Region. EACMCV[TZ7], the close relative of EACMCV-[TZ1], was found only in one sample in the same district of Mbinga. EACMV-[KE/TZT] was found only in the coastal areas, in ten samples, mainly in Tanga and Pwani regions. EACMV[KE/TZM] was found in ten samples, only in the Mara Region of the Lake Victoria Basin and to a very limited extent on the island of Ukerewe in Lake Victoria. The rest of the CMGs, EACMV-UG2 [TZ10], ACMV-[TZ] as well as EACMV-[TZ/YV], had a limited geographical distribution (Fig. 7).

\section{Comparisons of the East African and West African isolates of EACMCV}

i) Comparisons of the A components of EACMCV-[TZ]

The East African cassava mosaic Cameroon virus isolates from Tanzania (EACMCV-[TZ1, TZ7]) are very typical isolates of the species East African cassava mosaic Cameroon 


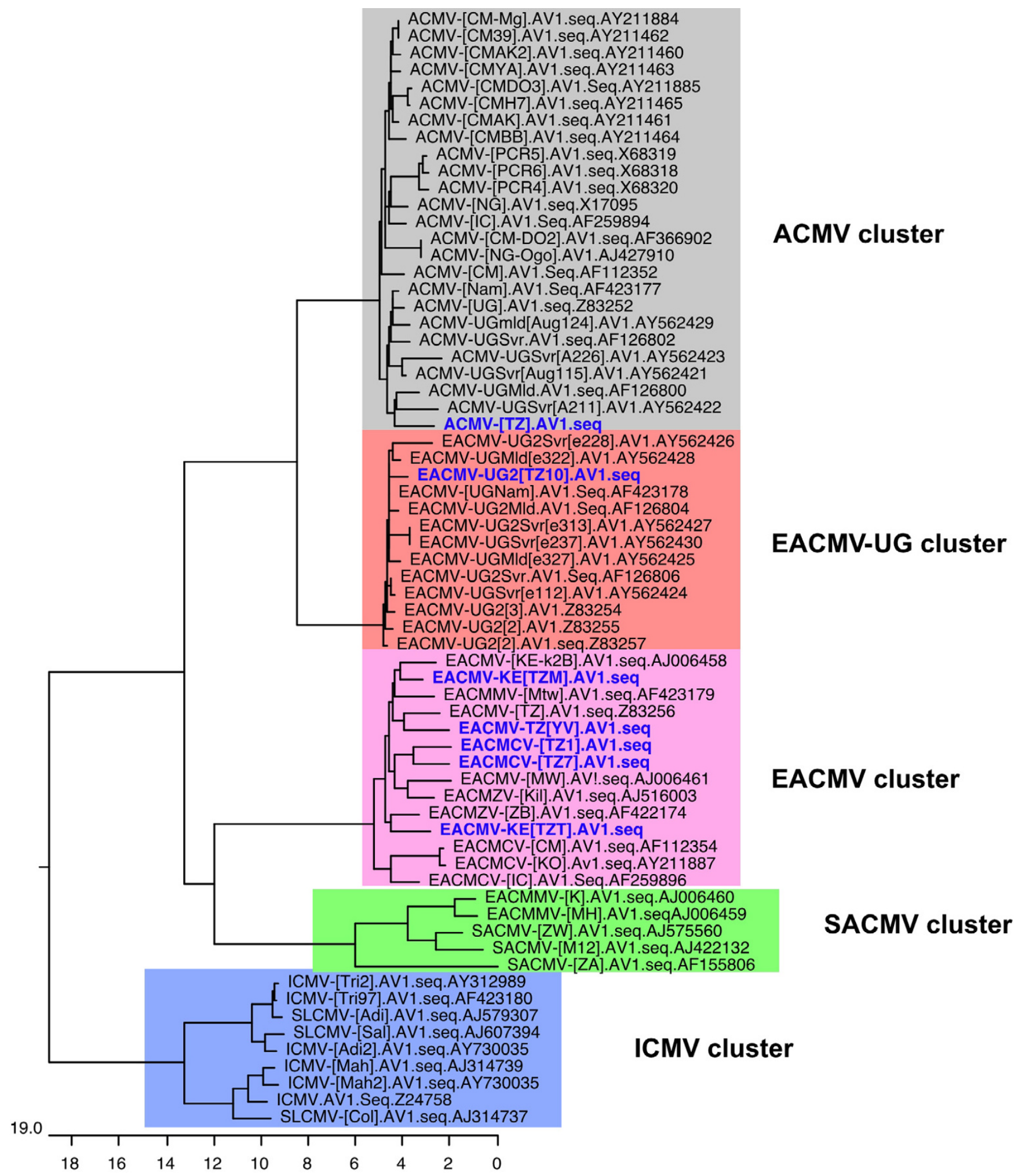

Figure 5

Phylogenetic tree of the coat protein gene (CP) nucleotide sequences of the cassava mosaic geminivirus isolates from Tanzania and other cassava begomoviruses ( 1000 bootstrap replications). Sequence of tomato golden mosaic virus (TGMV-YV) was used as the out-group. Abbreviations and accession numbers can be found in Figure 3. 
Table 4: Percent similarity (in the upper triangle) in the nucleotide sequence of the common region of East and West African isolates of EACMCV. Values of $89 \%$ and above are in bold.

\begin{tabular}{|c|c|c|c|c|c|c|c|}
\hline Virus isolate & $\begin{array}{l}\text { EACMCV- } \\
\text { [TZI] CRA }\end{array}$ & $\begin{array}{l}\text { EACMCV- } \\
\text { [TZ7] CRA }\end{array}$ & $\begin{array}{l}\text { EACMCV- } \\
\text { [TZI] CRB }\end{array}$ & $\begin{array}{l}\text { EACMCV- } \\
\text { [CM] CRA }\end{array}$ & $\begin{array}{l}\text { EACMCV- } \\
\text { [CM] CRB }\end{array}$ & $\begin{array}{l}\text { EACMCV- } \\
\text { [CI] CRA }\end{array}$ & $\begin{array}{l}\text { EACMCV- } \\
\text { [IC] CRB }\end{array}$ \\
\hline $\begin{array}{l}\text { EACMCV- } \\
\text { [TZI] CRA }\end{array}$ & ***⿰㇇⿰亅⿱丿丶丶 & 80 & 80 & 89 & 76 & 82 & 76 \\
\hline $\begin{array}{l}\text { EACMCV- } \\
\text { [TZ7] CRA }\end{array}$ & & $* * *$ & 86 & 88 & 74 & 82 & 73 \\
\hline $\begin{array}{l}\text { EACMCV- } \\
{[T Z I] C R B}\end{array}$ & & & 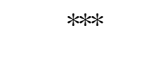 & 91 & 80 & 82 & 78 \\
\hline $\begin{array}{l}\text { EACMCV- } \\
\text { [CM] CRA }\end{array}$ & & & & $* * *$ & 86 & 91 & 83 \\
\hline $\begin{array}{l}\text { EACMCV- } \\
{[\mathrm{CM}] \text { CRB }}\end{array}$ & & & & & **** & 78 & 97 \\
\hline $\begin{array}{l}\text { EACMCV- } \\
\text { [CI] CRA }\end{array}$ & & & & & & **** & 77 \\
\hline $\begin{array}{l}\text { EACMCV- } \\
\text { [CI] CRB }\end{array}$ & & & & & & & $* * *$ \\
\hline
\end{tabular}

virus. The A component was 89 to $90 \%$ identical to the isolates from Cameroon and Ivory Coast and the 300 nts that differ are scattered all along the genome. In addition, the A components from East Africa showed the typical recombination already noted in the West African isolates, i.e. a fragment of about $800 \mathrm{nts}$ not of EACMV origin, covering AC2-AC3 and the C-terminus of AC1 (Fig. 8A).

\section{ii) Comparisons of the $B$ components of EACMCV}

The EACMCV West African isolates had only a stretch of 800 nts in the BC1 region in common with EACMV isolates from Uganda, the only B component available for EACMV: the rest of the sequence was completely different. The DNA-B of the East African EACMV isolates is $\pm 85 \%$ homologous to the West African isolates. The pairwise profile (Fig. 8B) showed the same recombinant fragment of about 800 nts with above $90 \%$ identity with West African isolates of EACMCV and other East African isolates such as EACMV-UG3, EACMZV and SACMV. The rest of the genome showed greater relatedness to the West African isolates of EACMCV, above the "species threshold" limit. Overall, the EACMCV-[TZ1] B component can be considered a non-closely related strain of the $\mathrm{B}$ component of EACMCV-[CM], but much closer than the B components of other East African cassava viruses.

\section{iii) Comparisons of the common regions (CRs) of EACMCVs from Cameroon and Tanzania}

The common region of A components (CRAs) were $82 \%$ to $89 \%$ identical to those of West African isolates, which is low but not abnormal as the West African isolates were 91\% identical to one another (Table 4). The differences are mostly in the variable region between the TATA box and the TAATATTAC stem-loop, but also in the rest of the sequence. The CR of $\mathrm{B}$ components (CRBs) of the EAC-
MCV-[TZ1] isolate was more distantly related, at between $78 \%$ and $80 \%$ homology to the CRBs of the West African isolates, while they were $97 \%$ homologous to one another. The differences were mostly in the variable region. When both (CRAs and CRBs) were compared, it was apparent that CRs of the East African isolates were more similar to the CRAs of West Africa than the CRBs of West Africa. This arises mainly from a deletion of GAAAA, and from a more similar sequence in the region between the TATA box and the stem-loop. The putative replication protein binding sequences (iterons) were GGTGG-AATGGGGG for all the isolates except for the Bs of West Africa where it is GGTGG-AAC-GGGGG. There is a repeat of GGGGG in the 5' end of the CRs for all the isolates (Fig. $6 B)$.

\section{Recombination analysis of cassava mosaic geminiviruses}

The pairwise analysis performed on all African cassava viruses sequenced so far, with two Indian cassava viruses as out-groups, and including the viruses isolated in Tanzania (here described), showed a number of putative recombinant fragments for both components. Figure 9 shows a genomic map for each component and summarizes the results obtained for the $\mathrm{A}$ and $\mathrm{B}$ components.

\section{i) Pairwise analysis of the A components}

African cassava mosaic virus

None of the ACMV sequences obtained so far exhibited a possible recombinant fragment. An isolate of ACMV was involved in a recombination between EACMV and ACMV to produce the EACMV-UG2 isolate, which was associated with the epidemic in Uganda in the 90s $[7,8]$. But it is worth noting that ACMV acted as a donor of DNA, not a receiver, in the recombination. The situation for the EACMV-like viruses is very different, as they exhibit mul- 


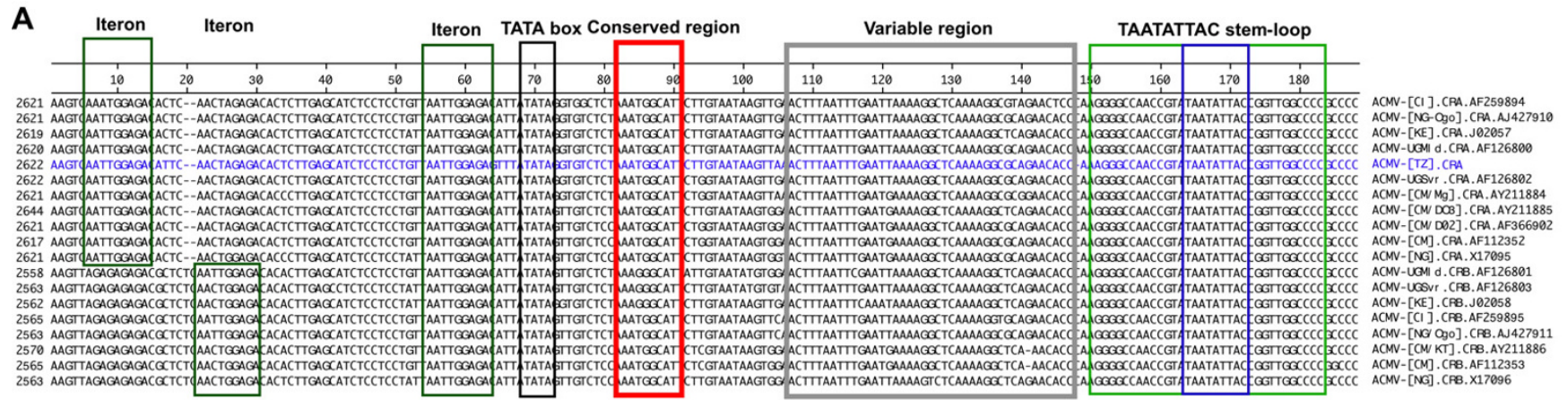

B

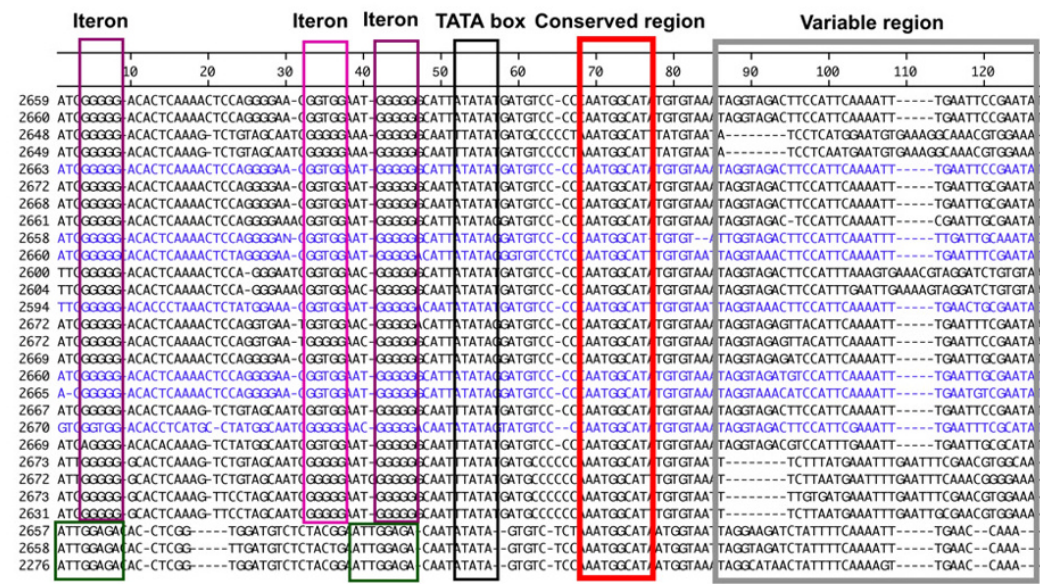

TAATATTAC stem-loop

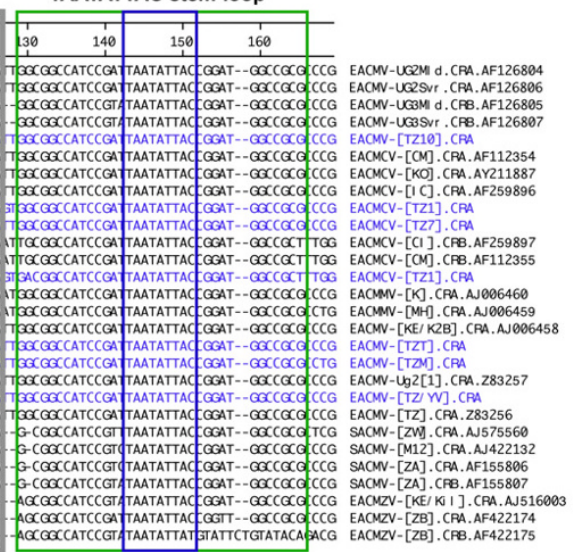

Figure 6

Alignment of common region (CR) nucleotide sequences of the DNA-A (CRA) and DNA-B (CRB) of ACMV (A) and EACMV (B) isolates from Tanzania with the related isolates of ACMV and EACMV from the database sequences. The TATA box for $\mathrm{ACl}$ is boxed in black. The putative Rep binding iterative sequences (iterons) are boxed in green and purple. The conserved nonanucleotide sequences TAATATTAC together with its stem loop are boxed in blue and green respectively. The conserved sequence 3'-end of the TATA box is boxed in red and the so-called "variable region" is boxed in grey. Virus sequences from Tanzania are written in blue. The accession numbers of the sequences from GenBank are indicated on the right of the virus abbreviation names and the significance of these abbreviations can be found in the legend of Figures 3 and 4 .

tiple putative recombinations between themselves and also unknown viruses. The A components of all the viruses in East Africa share a common backbone from EACMV and have integrated other pieces of DNA that have been said to originate from the other viruses not identified so far.

\section{East African cassava mosaic Zanzibar virus}

Two isolates of EACMZV from Zanzibar and Kenya [12] have most of their genomes from EACMV; approximately $200 \mathrm{nts}$ (2050 to $2250 \mathrm{nts}$ ) are similar to SACMV and the rest of the genome, covering $\mathrm{AC} 1, \mathrm{AC} 4$ and the $\mathrm{CR}$, is unique and therefore attributed to EACMZV or an ancestor of EACMZV (Fig. 9A).
East African cassava mosaic Cameroon virus

Several EACMCV isolates from Cameroon, Ivory Coast and now Tanzania (this report) belong to the species East African cassava mosaic Cameroon virus (see paragraph 3.6; [9]); all share the same putative recombinant fragment, i.e. a fragment of $800 \mathrm{nts}$ (AC3-AC2-CterAC1), that is unique and therefore attributed to EACMCV (Fig. 9A) or a common ancestor. However, the three isolates from West Africa do have a small recombinant fragment (100-250 nts) that is also unique to EACMCV, but this fragment is not present in the Tanzanian isolates.

\section{East African cassava mosaic Malawi virus}

Two virus isolates from the species East African cassava mosaic Malawi virus from Malawi (EACMMV-[K], -[MH]) 


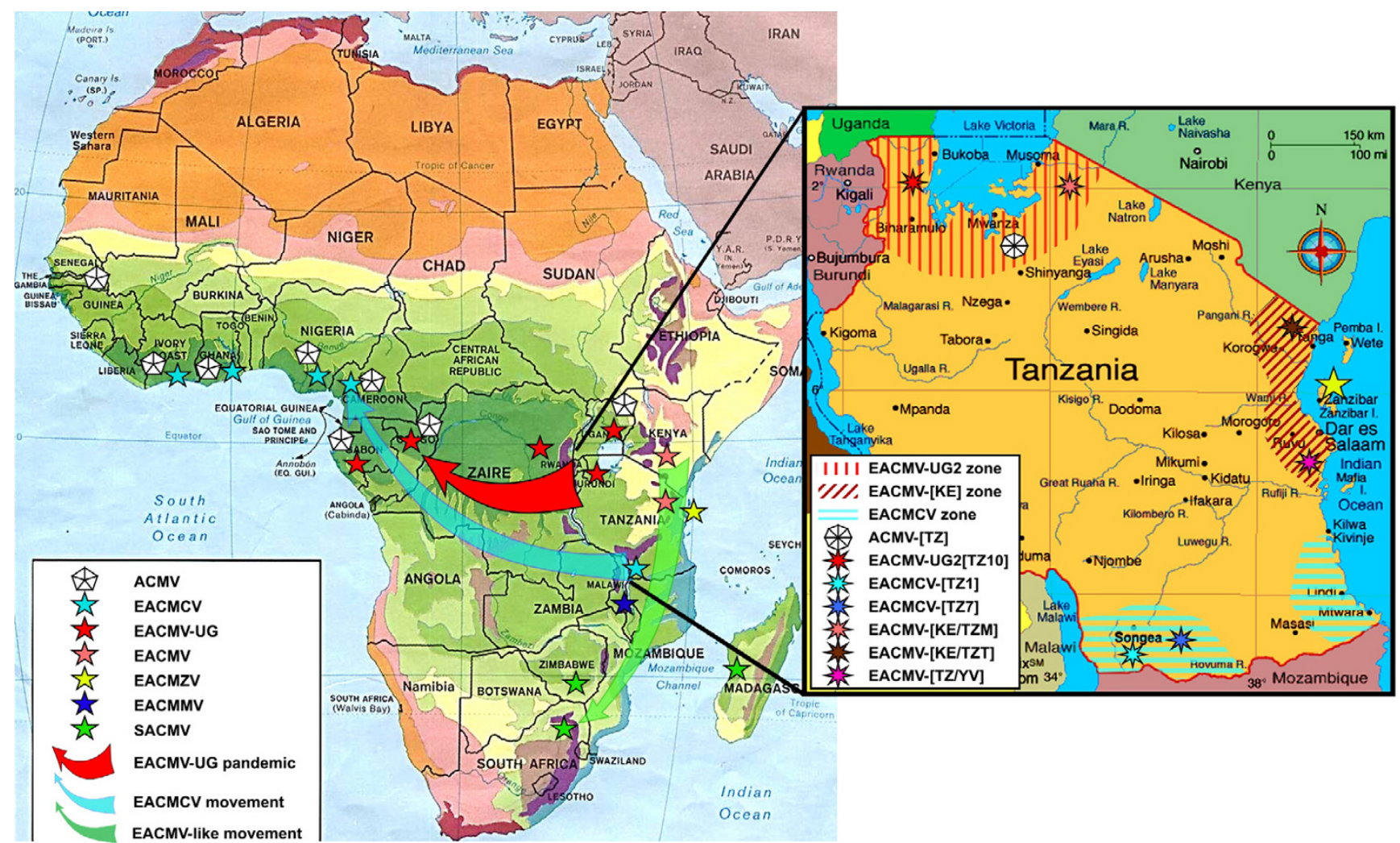

Figure 7

Map of the location of the different types of viruses present in Africa and inlay map of Tanzania showing the location of the completely sequenced CMG clones in that study as well as the localization of the distribution of viruses similar to these clones by RFLP mapping [13]. On the African map the symbols represent an approximate positioning of the viruses for which we have complete sequence information and not those for which we have either partial sequence information or serological data only. The significance of the different stars and shaded areas and arrows is indicated in the legend boxes in the figure. The solid red arrow represents the current direction of spread of the CMD pandemic, while the faded green and blue arrows represent possible "routes" of evolution of EACMV-like viruses and EACMCV in the past.

[15] show a similar recombination pattern. The first 1000 nts have either a similar pattern as SACMV-[M12] and SACMV-[ZW] or share two fragments of 100 and $750 \mathrm{nts}$ with the SACMV-[ZA] isolate from South Africa (Fig. 9A). The fragments 550-800 and 900-1050 nts are therefore attributed to EACMMV or an ancestor. The major difference with the SACMV isolates resides in the fact that the rest of the genome is purely EACMV-like, with the exception of $100 \mathrm{nts}$ in the AC1 gene (1950-2050 nts).

\section{South African cassava mosaic virus}

One virus isolate of the species South African cassava mosaic virus from South Africa (SACMV-[ZA]) [16] exhibited a putative recombination, i.e. most of the first $1000 \mathrm{nts}$ (CR, AV2 and most of AV1) and then the last $800 \mathrm{nts}$ (NterAC1, AC4 and CR) are unique for this virus and con- sequently attributed to SACMV, or an ancestor of SACMV. The rest of the genome, covering AC3-AC2 and the C-terminus of AC1, is typical of EACMV (Fig. 9A). Another two isolates of SACMV, one from Madagascar (SACMV[M12]) and one from Zimbabwe (SACMV-[ZW]), although belonging to the same species as the virus from South Africa, have a different recombination pattern, i.e. the first $1050 \mathrm{nts}$ are similar to EACMMV with portions that are SACMV-type and portions that are EACMMV-type (Fig. 9).

The SLCMV-[Col] and ICMV-[Mah] isolates, here used as out-groups [17], exhibited a large recombinant fragment of 1200 nts, possibly originating from ICMV [18] and encompassing NterAC1, AC4 and all the CR. 

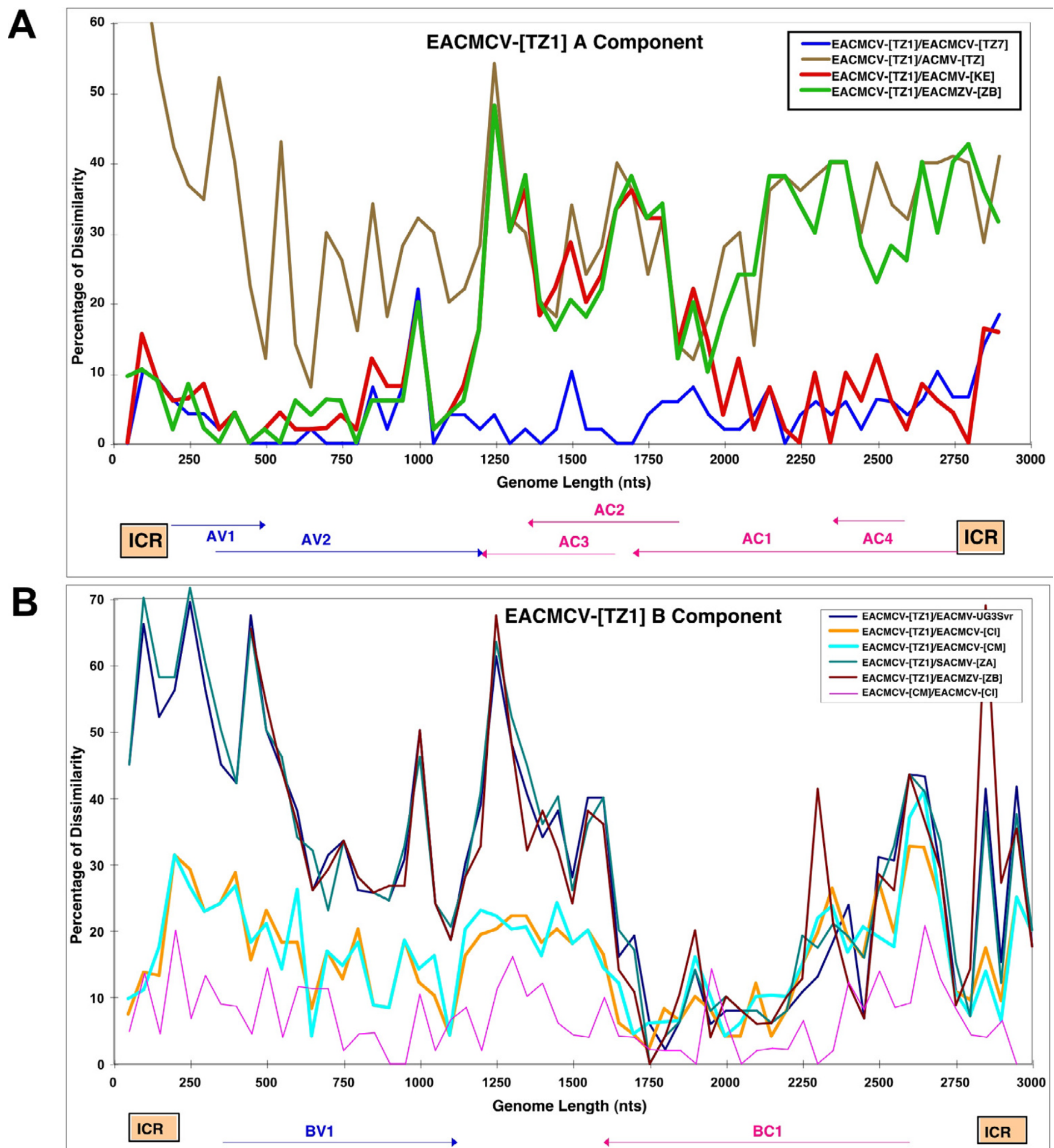

Figure 8

Pairwise sequence comparisons of EACMCV-[TZI, TZ7] DNA-A (A) and DNA-B (B). Each curve represents a sequence comparison along the linearized virus genomes of a chosen pair of viruses. The correspondance for each colored curve is given in the figure. The dissimilarity index ( $Y$ axis) is the percentage of dissimilarity over a window of 50 nucleotides. The curves under $10 \%$ represent a pair of isolates of the same species and curves above $10 \%$ represent a pair of isolates belonging to different species. A switch between the two types of curves represents a putative recombination between the two viruses or their ancestors. The linearized genome organization of each component is depicted at the bottom. 


\section{A Cassava Geminivirus A Components}

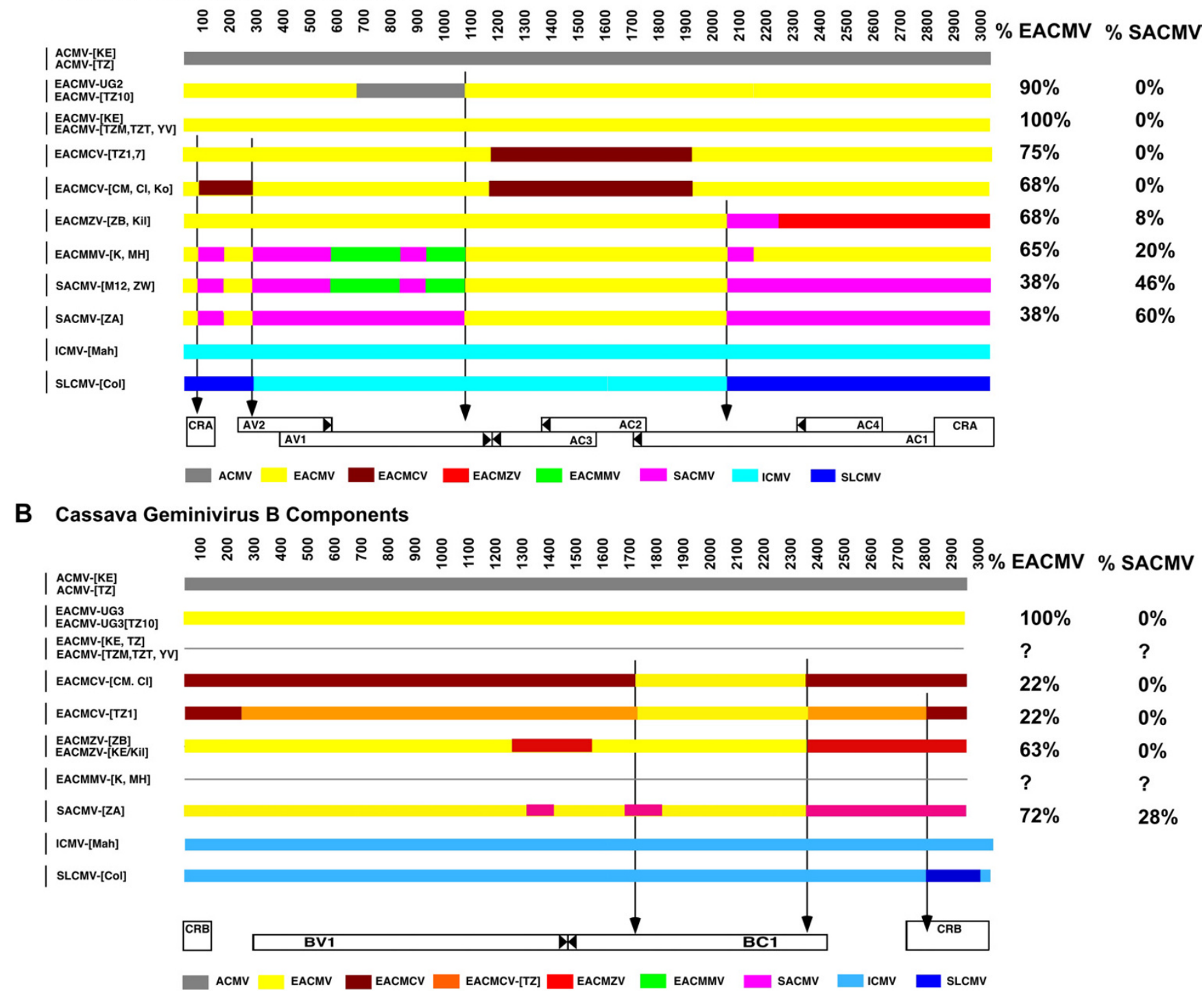

Figure 9

Recombination linearized map of putative recombinant fragments for the A (top) and B (bottom) components of cassava mosaic geminiviruses. Each horizontal line represents the genotype of one virus isolate and the color-coded boxes represent the tentative origins of the putative recombinant fragments. The length of the genomes is indicated on the top of each diagram and the genome organization is depicted at the bottom, while the abbreviated names of the viruses are listed on the left. The color code for the recombinant fragments is indicated in the boxes at the bottom of each diagram. The vertical arrows indicate the position of possible "hot spots" for recombination. On the right side are listed the percentages of EACMV-type and SACMV-type sequences for each virus.

Noticeably, several recombination sites are aligned among the different genomes, possibly indicating "hot spots" for recombination and possibly also delineating fragments in which variation led to selective evolutionary advantage. ii) Pairwise analysis of the $B$ Components

The B components of CMGs also showed the presence of putative recombinant fragments as determined by the pairwise analysis. Unfortunately, some $\mathrm{B}$ components, such as those of EACMV-[TZ], EACMMV-[K] and -[MH], 
have not been cloned yet and therefore we have only partial information. The ACMV B sequences available did not show any recombination. The EACMCV isolates from Cameroon, Ivory Coast and Tanzania all showed the same putative recombinant fragment, i.e. between 1700 and 2300 nts, corresponding to part of the $\mathrm{BC} 1$ gene. Interestingly, and a contrario to the EACMCV A component, most of the $B$ genome is unique and only the recombinant fragment originates from EACMV (Fig. 9B); the rest of the genome is therefore marked as the EACMCV-type (Fig. 9B). Furthermore, a comparison of the B components of the EACMCV isolates from Cameroon or Ivory Coast with the sequence from Tanzania shows between 250 and 1700 nts and between 2350 and $2800 \mathrm{nts}$, a different sequence, indicating either another two recombinations with another unknown virus or viruses, or, as supported by the number of point mutations, an extremely old sequence compared to the West African isolates of EACMCV (Fig. 9B); therefore it is marked EACMCV-[TZ]. On the contrary, the partial sequence of the $B$ component of an isolate from Zanzibar (EACMZV-[ZB]) showed almost complete identity with a B component from EACMV-UG3, with a very short EACMZV-type fragment of $150 \mathrm{nts}$ at the end of the genome. Similarly, the sole isolate of a B component of SACMV-[ZA] was almost entirely identical to EACMV-UG3, with a $500 \mathrm{nts}$ fragment SACMV-type (1700 - $2300 \mathrm{nts})$, mostly corresponding to a non-coding fragment of the virus. ICMV and SLCMV B components, here used as out-groups, were essentially identical with the exception of $200 \mathrm{nts}$ covering the CR of SLCMV and justifying the claim that the SLCMV A component captured the B component of ICMV [17].

\section{Quantification of the percentage of EACMV-type and SACMV-type sequences in each virus}

From the recombination analysis and phylogenetic results, it is clear that all EACMV-like viruses share a portion of the EACMV backbone sequence. The recombination map was used to calculate these percentages, indicated in Figure 9 for each component. This percentage varies from 38 to $100 \%$ depending on each virus for the $\mathrm{A}$ components and from 22 to $100 \%$ for the B components. A similar calculation can be made for sequences that are SACMV-type and the results vary between 0 and $60 \%$ for the A components and from 0 to $16 \%$ for the B components (Fig. 9). Figure 11 shows a repartition of these percentages according to the different viruses cloned and according to a transect between Uganda and South Africa, indicating that the EACMV backbone sequence decreases towards South Africa while the SACMV-type sequence increases.

\section{Discussion}

The present study confirmed the presence of representatives of 3 species of CMGs in Tanzania: one isolate of
ACMV, four isolates of EACMV, and two additional isolates of EACMCV. The complete DNA-A nucleotide sequences of these isolates were determined.

\section{ACMV}

It is apparent from the results of this study that several CMGs exist in Tanzania showing a high genetic diversity. The ACMV characterized from Tanzania was found to have very high overall DNA-A nt sequence identity to all the other isolates of ACMV sequenced so far. As there is no relation between the origin of ACMV isolates and their sequence relationship with other isolates, it is impossible to tell if the one found in Tanzania is more related to one ACMV isolate than another. As it is the first isolate to be sequenced from Tanzania, we named it ACMV-[TZ]. This virus, like all the other ACMVs, displayed no detectable recombination in its DNA-A genome.

\section{EACMCV}

EACMCV-[TZ1] and EACMCV-[TZ7] had high overall DNA-A nt sequence identities, as well as high CP and CR sequence identity to members of the species EACMCV from West Africa, confirming their relatedness to that species. The two isolates from Tanzania are about $8 \%$ different, while each of them is more than $10 \%$ different to any of the West African isolates. The two Cameroonian isolates are very close to one another (>99\%) and about 3$4 \%$ different from the Ivorian isolate. In addition, the Tanzanian viruses showed the same recombination, relative to EACMV-type sequences, as the EACMCVs from Cameroon and Ivory Coast, covering the C-TerAC1-AC2-AC3 region. However, we noted that the Tanzanian isolates have lost or never acquired a small recombinant sequence at the beginning of the genome, as present in the West African isolates. The EACMCV-[TZ1] B component showed the same recombination as the EACMCV-[CM] and EACMCV-[CI] B components, covering part of the $\mathrm{BC} 1$ region. However, the EACMCV-[TZ1] B component had an additional two putative recombinant fragments (250-1700 nts and 2350-2800 nts) not present in the West African isolates. Considering the overall sequence identity of both components, the fact that sequence differences are scattered all along their genomes and the fact that there are differences in patterns of recombination, it is strongly suggested that the two sets of viruses from East and West Africa have been separated for a very long time and are not the result of a recent introduction in either direction. One recombination in DNA-A and one in DNA$\mathrm{B}$, as they are identical, pre-date their separation, though it is not possible at this stage to date the separation. EACMCV-[TZ1] occurred widely in southern Tanzania, being present in over $98 \%$ of CMD-diseased samples collected from the southwestern part of Tanzania in the Ruvuma Region close to Lake Malawi in the same area where EACMCV-[TZ7] was found. The fact that the two sequences in 


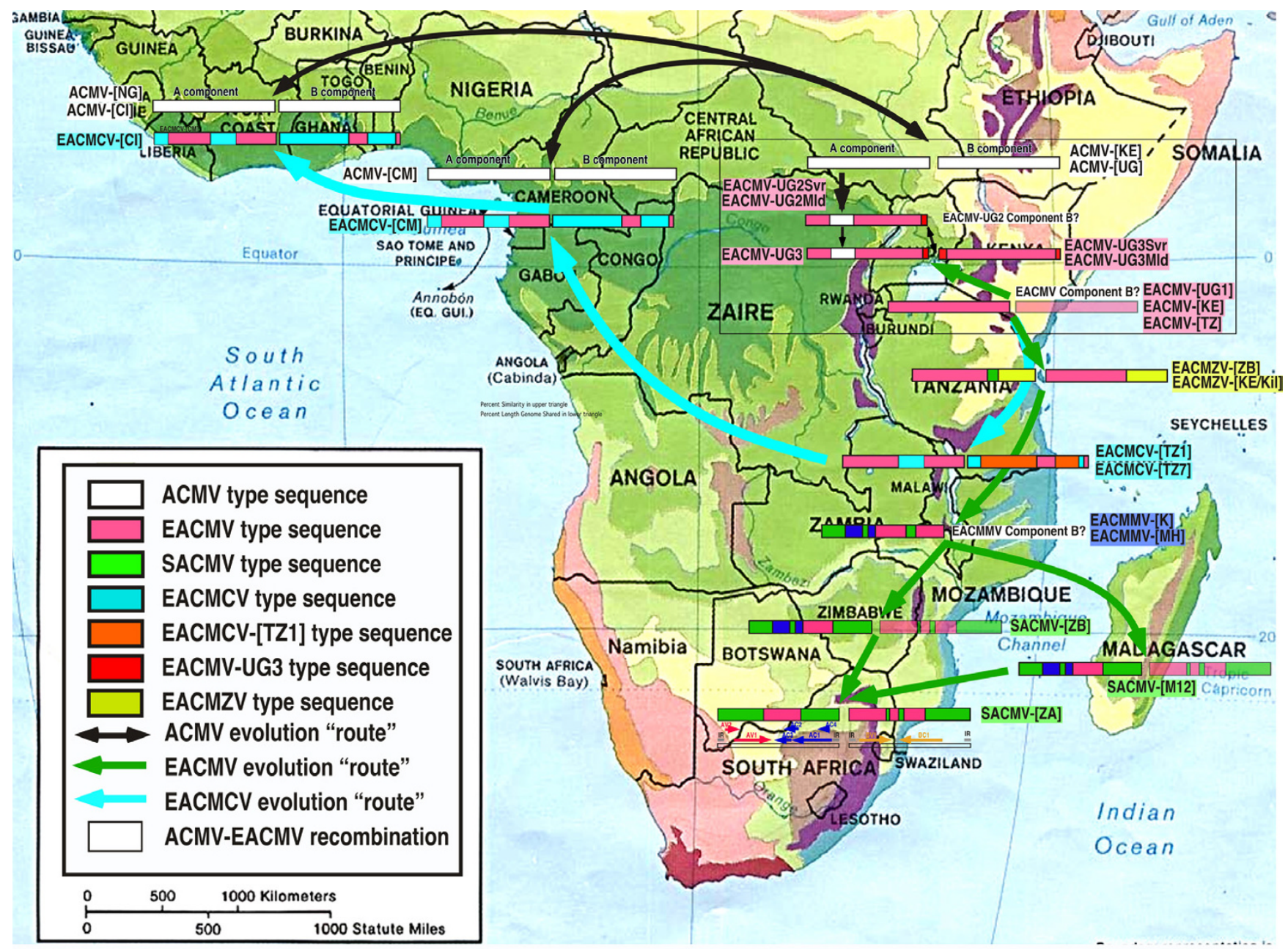

\section{Figure I I}

Map of Africa depicting the putative inter-species recombinations of components $A$ and $B$ of cassava mosaic geminivirusess identified in different parts of Africa, either from this study or from GenBank accessions. The significance of the color codes is given in the figure. Where the component $B$ of a particular virus has not been cloned, it is indicated in letters for a different species representative or as a faded drawing for a different isolate. For simplification of the drawing, not all the ACMV isolates have been shown as they are very similar. Similarly, the EACMV-UGs associated with the CMD pandemic now present in several central African countries have not been depicted as they are of very recent introduction (less than 10 years). The solid blue arrows represent the possible "route" of evolution of the EACMCV viruses, and the green arrows represent the possible "route" of evolution of the EACMV viruses.

Tanzania show from two to three times more sequence variability and two extra recombinant fragments, together with the fact that the parent EACMV has not been found so far in West Africa, suggests an East African origin of this virus species, and therefore a possible spread from the East to the West as indicated in Figure 10.

\section{EACMV-TZ, -KE, -UG}

The rest of the CMGs cloned in this study were closely related to those reported in the neighboring countries of
Uganda, Kenya or the previously characterized Tanzanian isolate of EACMV. These were EACMV-[TZ/YV], which resembled the EACMV-[TZ] characterized previously [19], and EACMV-[KE/TZT] that showed high sequence identity with EACMV-[KE/K2B] from Kenya, on the basis of their overall DNA-A nt sequences. While the CP of EACMV[TZ/YV] showed high sequence identity with EACMV-[TZ] and EACMZV-[ZB] from the island of Zanzibar [12], EACMV-[KE/TZT] from Tanga region showed high nt sequence identity with its close relative EACMV-[KE/K2B]. 


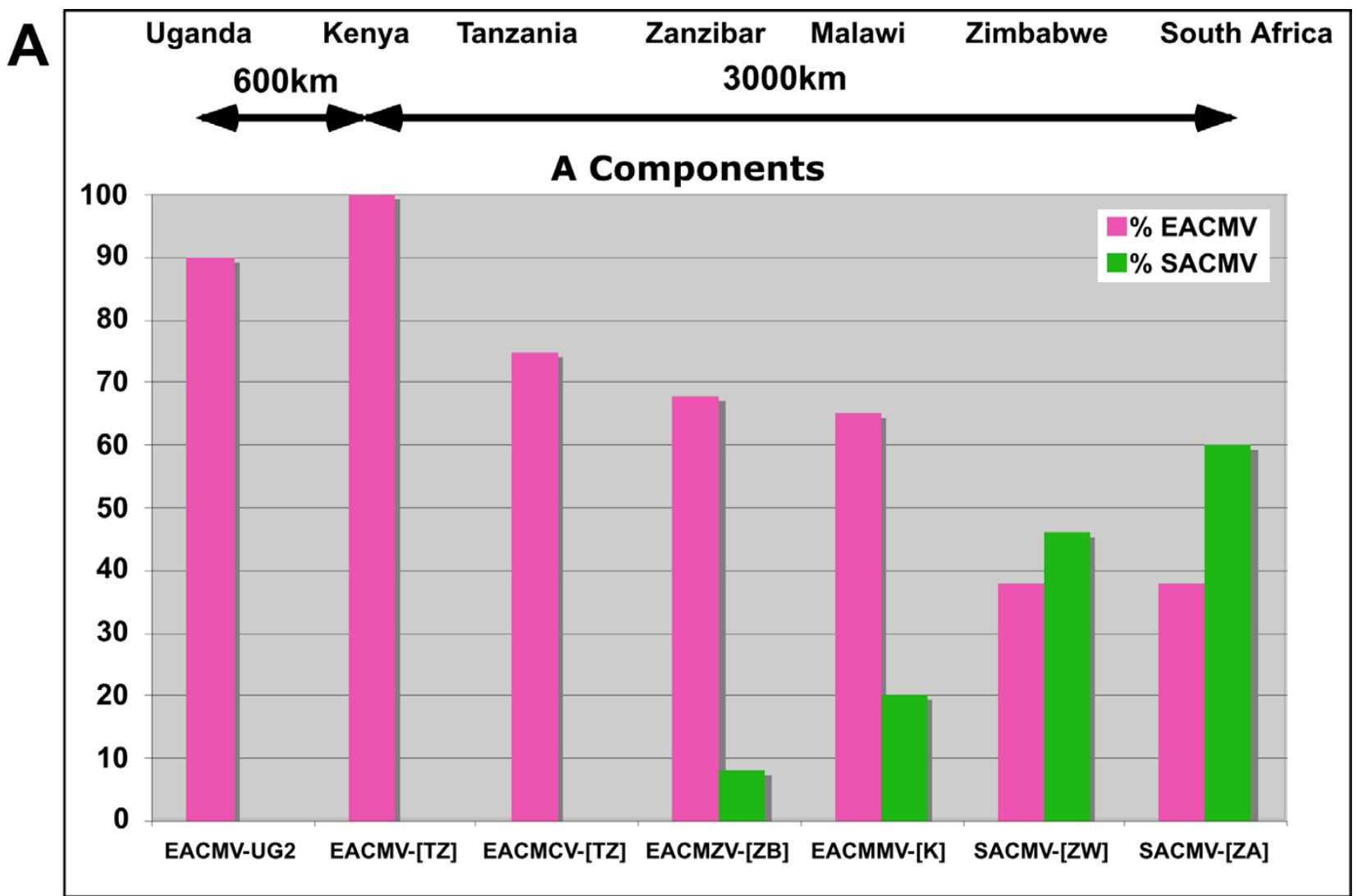

B

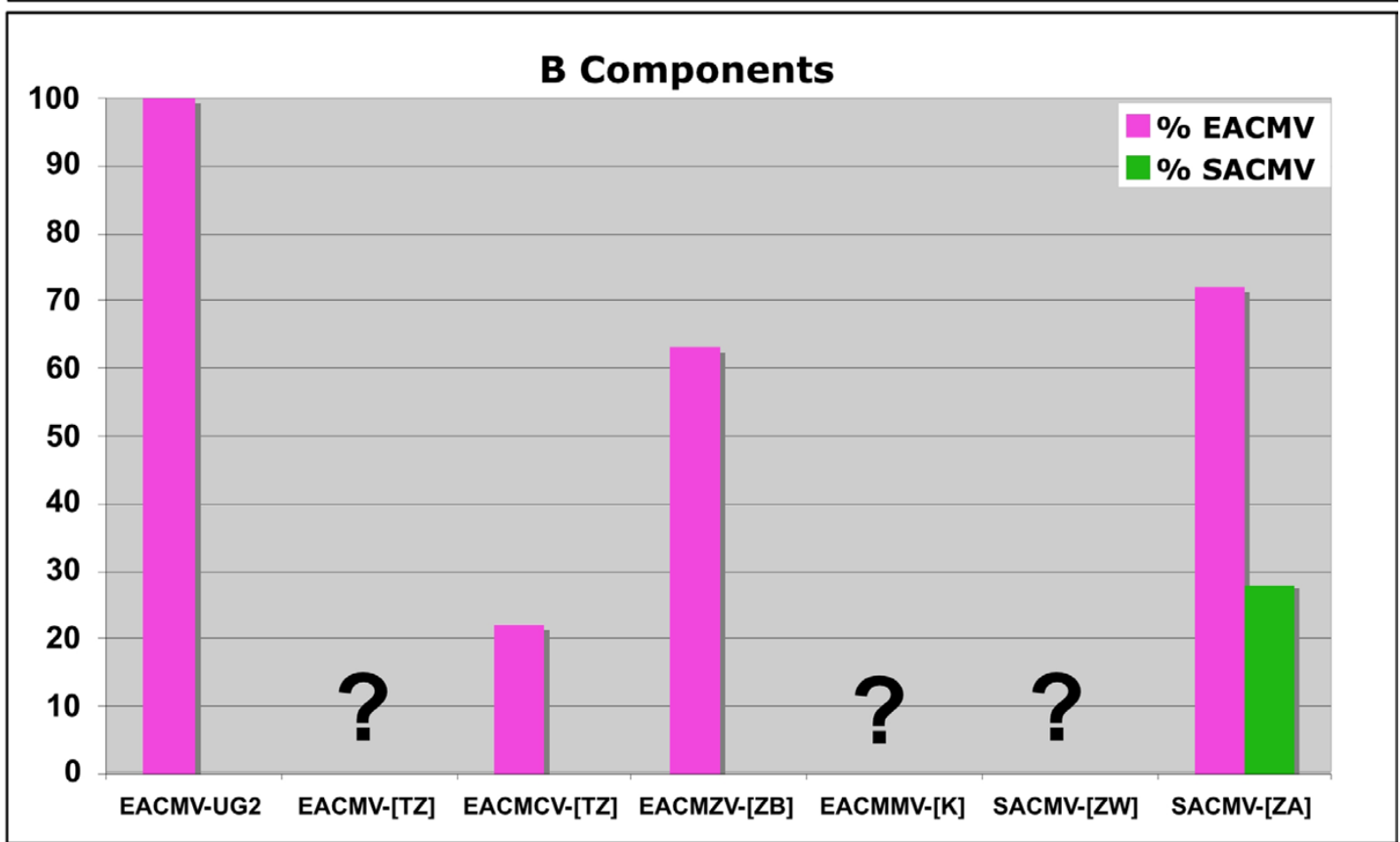

Figure 10

Graph representing the proportion of EACMV-type and SACMV-type sequences in each virus isolated along a transect from Uganda (Left) to South Africa (Right) for their A components (A) and B components (B). The virus name abbreviations are given in the legend of Figures 3 and 4 and throughout the text. 
Similarly, EACMV-[KE/TZM] also shared high CP nt sequence identity with EACMZV-[ZB]. It was found in only ten samples and very localized in spread within the region. Plants singly-infected with EACMV-[KE/TZM] expressed very severe symptoms both in the field and growth chamber. Whether this phenotype was a result of the nature of the EACMV-[KE/TZM] DNA-A genome remains to be established. The EACMV-UG2 [TZ10] shared very high DNA-A and CR sequence identity with EACMV-UG2Svr from Uganda. The CR also showed 100\% nt sequence identity with EACMV-UG2Svr as well as high $\mathrm{CP}$ sequence identity to ACMV isolates because it has the same recombination as its closest relative, EACMVUG2Svr, that was proven to involve two viruses (ACMV and EACMV) $[7,8]$. This CMG was localized in the northwestern part of Tanzania in the post-epidemic area. It is noticeable that this virus, which has invaded a large portion of Central Africa in just a few years [4] (Fig. 8), has not yet reached the southern and eastern part of Tanzania.

\section{Recombination of $A$ and $B$ components}

Using all the CMG sequences available so far, we have shown that both $\mathrm{A}$ and $\mathrm{B}$ components of most of the CMGs exhibit putative recombinant fragments from various known or unknown origins. Despite the smaller number of sequences of DNA-B components and the smaller number of putative recombinant fragments, it is interesting to note that, as for the A components, it seems that there are "hot spots" for recombination. These apparent hotspots for recombination could result from physical constraints in the virus sequences or could simply result from the functional constraints of having recombinant proteins that keep structural and biological functions. These hotspots have already been mentioned in other general studies of geminivirus recombination [14] as well as in specific studies of particular groups of geminiviruses [20].

\section{Two categories of CMGs in Africa}

Based on recombination analyses, it is apparent that there are really two different categories of CMGs. The ACMV group does not have fragments of foreign geminivirus DNA in their genomes. By contrast, all other African CMG species groups show evidence of extensive recombination. It is also significant that EACMCV isolates obtained from each side of the African continent appear to share a similar genetic make-up and recombination pattern. This suggests that these viruses had a common origin, probably in East Africa, but diverged a long time ago. Recombination events have been shown to be key factors in the development of CMD epidemics $[7,8,19]$ and it has been suggested that recombination is a significant contributor to geminivirus evolution [14]. Recombination involving the CP sequence has been reported for EACMV-UG2 from Uganda $[7,8,10]$, a virus that has been associated with the current CMD pandemic that has devastated cassava in eastern and central African countries [4,21], although there is currently no proof that this event has been the key factor driving the pandemic's spread.

\section{B components of CMGs in Tanzania}

The diversity of DNA-B components of EACMV from Tanzania was investigated using partial DNA-B nt sequences (BC1-CR) of 560 bp. Generally, there was little genetic divergence among the compared isolates with the exception of TZB6 that shared $97 \%$ sequence identity to EACMV-UG1 (AF230375) and 96\% with EACMV-UG3 from Uganda. Isolate TZB1 and TZB7 clustered with EACMCV-TZ1 and are probably Bs of EACMCV A components. However, for the other isolates that grouped or formed their own group in the phylogenetic analysis, it was difficult to speculate as to what they represent partly because the DNA-Bs of EACMV-[TZ], EACMV-[KE] and EACMMV have yet to be sequenced. However, these short fragments indicated a clustering, apart from EACMV-UG and $\mathrm{EACMCV}$, into 4 additional clusters that could reflect an even greater molecular diversity in the B components of CMGs in East Africa than we currently recognize.

\section{EACMV evolution}

The clustering of all the EACMV-like viruses into one species has been the topic of much scientific debate in recent years. ICTV (International Committee on Taxonomy of Viruses) finally decided to split them into 5 species (for now), mostly to comply with the ICTV guidelines for species demarcation, but clearly these viruses are closely related and had common ancestors. All EACMV-like viruses with the exception of EACMCV occur in East Africa, and mostly east of the Rift Valley. Evidence presented here and elsewhere now provides a strong case for an East African origin for the EACMVs. EACMCV is widely-distributed across West Africa, albeit at low incidence [4]. Whilst it seems likely that this is the result of an early introduction or introductions from East Africa, it is not currently clear when such an introduction(s) might have taken place. It is even possible that the spread of this virus occurred in another host, long before cassava was introduced into Africa.

Finally, the rapidly expanding EACMV-UG2 associated pandemic of severe CMD in East and Central Africa represents a contrasting, and currently probably unique, scenario in which the combination of a virulent recombinant virus, superabundant vector populations and susceptible local cassava germplasm have led to a rapid expansion in the geographic range of EACMV-UG with a concomitant devastating impact on cassava cultivation. Furthermore, it is significant that when considering the proportion of pure EACMV backbone sequences in the A components of all the EACMV-like viruses, there is a clear 
gradient from East Africa to South Africa, going from 100 to $38 \%$, suggesting firstly that these viruses are highly related and secondly that the origin of the EACMVs might have been East Africa, hence the green arrows in Figures 8 and 11. Similarly, a reverse gradient for the SACMV-like sequence, going from 8 to $60 \%$ from Zanzibar to South Africa, suggests that the SACMV ancestor was located in South Africa. Because recombination can only occur when the two parent viruses are in the same plant, it is logical to expect a spatial relation between the different viruses and their genetic make up. It is, however, the first time that such gradients have been demonstrated for geminiviruses. The situation for the B components is completely different. There is no EACMV-like gradient from North to South, as most of the available sequences show a great proportion of EACMV-like sequences. However, it is evident that EACMCV has captured a B component completely different from EACMV, with only a small EACMVlike fragment. This result is concordant with the idea that $\mathrm{B}$ components can be recruited independently from the genetic nature of A components as already suggested for SLCMV and ICMV [17].

\section{East Africa}

East Africa has been the cradle for many biological organisms beginning with humanity. From this work, it is also apparent that Tanzania may also be a potential source of origin of the family of EACMVs. The revealed strain diversity further exemplifies the wealth of this part of Africa with respect to cassava geminiviruses. Some of these viruses have been introduced very recently, such as EACMV-UG2 [TZ10], while others, such as ACMV and the EACMVs, have clearly been present much longer. The East-African Arc Mountain is known to be the main biodiversity hot-spot in Africa, and an important refuge for plants and animals [22], therefore it is plausible that some of the geminiviruses that were invading local host plants were spread throughout Africa in their local hosts (for many millions of years), as it was suggested for Rice yellow mottle virus [23] colonizing the domesticated host in very recent history (a few hundred years). The same type of geminiviruses would have colonized cassava wherever they might be, beginning with that crop's introduction into the African continent in the $\mathrm{XVI}^{\text {th }}$ century, as these viruses would have had the same potential for such colonization. This might have been the case for EACMCV for which our data presented here suggest an old East African origin for the now widely distributed EACMCV in West Africa. In addition to this scenario, it is certain that cassava geminiviruses have been exchanged throughout the movement of virus infected cassava cuttings via human intervention and by the natural vector Bemisia tabaci. The latter may account for the EACMV/SACMV gradient between East Africa and South Africa, favoured by a natural corridor along the eastern Rift Valley and created by the recombination capacity of CMGs present in the same region.

However, more sequences are required in order to compare and contrast variability within and between the virus populations and to strengthen the understanding of their evolutionary interrelationships. The rapid spread of the EACMV-UG2 associated pandemic has been driven through superabundant whitefly populations [24], but other important forces in CMG movement and evolution include movement of cassava cuttings and transmission from and into alternative weed hosts. Although cassava was brought to Africa in the XVI ${ }^{\text {th }}$ century, it attained its current Africa-wide distribution as recently as the XIX ${ }^{\text {th }}$ century. Most current movement occurs informally as farmers move cuttings locally. Wider distribution is less frequent but may be more significant in enabling major displacements of CMGs, such as that hypothesized for the introduction of EACMCV from East to West Africa. Although rapid spread of up to $100 \mathrm{~km}$ per year has been reported for the EACMV-UG associated pandemic [4], elsewhere there appears to be much less local spread of CMGs by whitefly, and physical barriers including lakes, forests and regions where cassava is not grown, appear to be effective in curtailing local spread of CMG. This would seem to account for the apparent 'island' of EACMCV in southern Tanzania as well as the absence of ACMV from coastal East Africa.

\section{Conclusion}

In conclusion, we have established the existence of different CMG isolates, strains and species in Tanzania with some isolates resembling those reported previously in East African countries and two isolates very similar to the geographically distant EACMCV from West Africa. This study demonstrates that East Africa is rich in CMGs and could be the cradle for CMG diversification in Africa. It also highlights the urgent need for more information. Only through building a thorough understanding of these important plant pathogens and the evolutionary processes underpinning their emergence can we hope to develop effective and sustainable approaches to managing the disease they cause.

\section{Methods \\ Collection of plant samples}

A total of 510 samples were collected during September 2002 from the northeastern coast (60), east coast (74), southeastern coast (68), southern region (70) and the Lake Victoria Basin (238), representing the major cassavagrowing areas in Tanzania. Cassava leaf samples and cuttings $(25-30 \mathrm{~cm}$ in length) were collected from plants expressing CMD symptoms in fields located at a minimum of $5 \mathrm{~km}$ intervals. Leaf samples were kept in a cool box for DNA processing. Selected cassava cuttings were 
transported to the Donald Danforth Plant Science Center, St. Louis, MO for replanting in controlled growth chambers.

\section{Symptom reproduction in the growth chamber}

Selected cassava cuttings collected from the fields were planted in a growth chamber at $25^{\circ} \mathrm{C}$ with a 16 hours day length and 50\% relative humidity and watered twice weekly. CMD symptoms were recorded daily on the newly formed leaves for the first three months and every three days in the subsequent months for an eight month period. Symptom severity on the top five fully-expanded leaves was scored using a scale described by Fauquet et al [25].

\section{DNA extraction}

Total DNA was extracted from the symptomatic cassava leaves collected in the field and growth chamber as described by [26].

\section{Polymerase chain reaction, cloning, and sequencing}

Full-length copies of DNA-A were amplified from total cassava plant DNA extracts using sets of primers (Table 1). $\mathrm{UNI} / \mathrm{F}$ and UNI/R are degenerate primers with annealing positions in the AC1 gene designed to amplify near fulllength DNA-A of CMGs (2.7-2.8 kbp) leaving an unamplified portion of $\sim 17$ nts. From the near full-length CMG sequences, primers were designed to amplify the remaining partial DNA-A sequences including the missing $17 \mathrm{nts}$ from the original samples. Partial fragments consisting of a region between the $\mathrm{BC} 1$ gene and intergenic region (IR) of DNA-B components of EACMV isolates from different cassava-growing areas were amplified by universal primers EAB555-F and EAB555-R (Table 1) designed to amplify PCR products of about 540-560 kbp depending on the virus isolate. In order to amplify the DNA-A and DNA-B full-length, PCR was performed with $94^{\circ} \mathrm{C}$ denaturation followed by 35 cycles of $1 \mathrm{~min}$ at $94^{\circ} \mathrm{C}, 59^{\circ} \mathrm{C}$ for $1 \mathrm{~min}$ and $2 \mathrm{~min}$ at $72^{\circ} \mathrm{C}$. For amplification of the partial DNA-B fragment (BC1/IR), PCR conditions were 30 cycles of $94^{\circ} \mathrm{C}$ for $1 \mathrm{~min}, 55^{\circ} \mathrm{C}$ for $1 \mathrm{~min}, 72^{\circ} \mathrm{C}$ for $1 \mathrm{~min}$ and an extension cycle of $10 \mathrm{~min}$ at $72^{\circ} \mathrm{C}$. PCR products of the expected sizes were electrophorezed in a $1 \%$ agarose gel in TAE buffer (10 mM tris-acetate, $1 \mathrm{mM}$ NaEDTA, pH 8.0), purified, and cloned into the pCR 2.1 vector using the TA cloning kit (Invitrogen, San Diego, CA). Clones containing putative viral sequences were identified by miniprep screening and confirmed positive for inserts by PCR amplification using their respective PCR primers, and inserts were subsequently sequenced in both directions. The complete and partial nucleotide sequences of CMGs were determined by the dideoxynucleotide chain termination method using an ABI automatic sequencer on both orientations at the Protein and Nucleic Acid Chemistry Laboratories (PNACL), Washington University School of Medicine, St. Louis, Missouri, USA (ABI377
DNA sequencer, Perkin Elmer, Foster City, CA). Sequence fragments of $<600 \mathrm{kbp}$ were generated using M13 universal primers. Moreover, to obtain overlapping data from opposite strands of large or full-length fragments, single primers were constructed for genome walking. Sequences were submitted to GenBank and the accession numbers are as follows: Complete nucleotide sequence of DNA-A named EACMCV-[TZ1] (AY795983); EACMCV-[TZ7], (AY795984); EACMV-UG2 [TZ10], (AY795988); EACMV[KE/TZM] (AY795986); EACMV-[KE/TZT], (AY795985); EACMV-[TZ/YV], (AY795987); ACMV-[TZ] (AY795982); and DNA-B for EACMCV-[TZ1](AY795989). Partial DNA$\mathrm{B}$ (BC1/ICR) sequences of EACMV isolates from Tanzania named TZB (AY800251), TZB1 (AY800252), TZB2 (AY800253), TZB3 (AY800254), TZB4 (AY800255), TZB5 (AY800256), TZB6 (AY800257), TZB7 (AY800258), TZB8 (AY800259), TZB9 (AY800260), TZB10 (AY800262), TZB11 (AY800261), and TZB12 (AY800263).

\section{Computer analysis of CMG sequences}

Virus sequences were edited using BioEdit Sequence Alignment Editor (Hall, 1999) and SeqEdit (DNAStar, Madison, WI) to obtain a consensus sequence for each. Reference geminiviruses for full length $\mathrm{CP}$ and $\mathrm{CR}$ sequence alignments were compiled by extracting the complete DNA-A and DNA-B sequences, the CP ORF (approximately 765-777 bp) and CR sequences (approximately 150-170 bp) from sequences available in GenBank (accession \# are provided in the figures). Multiple sequence alignments of the full-length DNA-A, DNA-B, capsid protein $(\mathrm{CP})$ gene and common region (CR) were carried out using the Clustal Program (MegAlign, DNAStar). The phylogenetic trees were constructed from the multiple alignments by the neighbor-joining majority rule consensus. Multiple alignments were analyzed by maximum parsimony with full-length DNA-A, DNA-B and CP phylogenetic trees using Phylogenetic Analysis Using Parsimony (PAUP) [27] and a bootstrap analysis with 1000 replicates was performed. Only values above $50 \%$ were reported on the trees in the figures. Virus specific iterons in the CR of selected CMGs were identified and compared with the analogous iterons of the Tanzanian isolates of CMGs.

\section{Recombination analysis for cassava mosaic geminiviruses}

The pairwise comparison sequence analysis (PCSA) method compares the profile of a pair of sequences to that of an average profile of sequences that are selected $a$ priori, based on knowledge that the selected sequences are related to the species or the isolate levels [20]. According to the guidelines established by the ICTV Geminiviridae Study-Group, two geminivirus sequences sharing more than $89 \%$ identity of their A component sequences are considered strains or isolates of the same species. Where homology is less than this, they are considered to be 


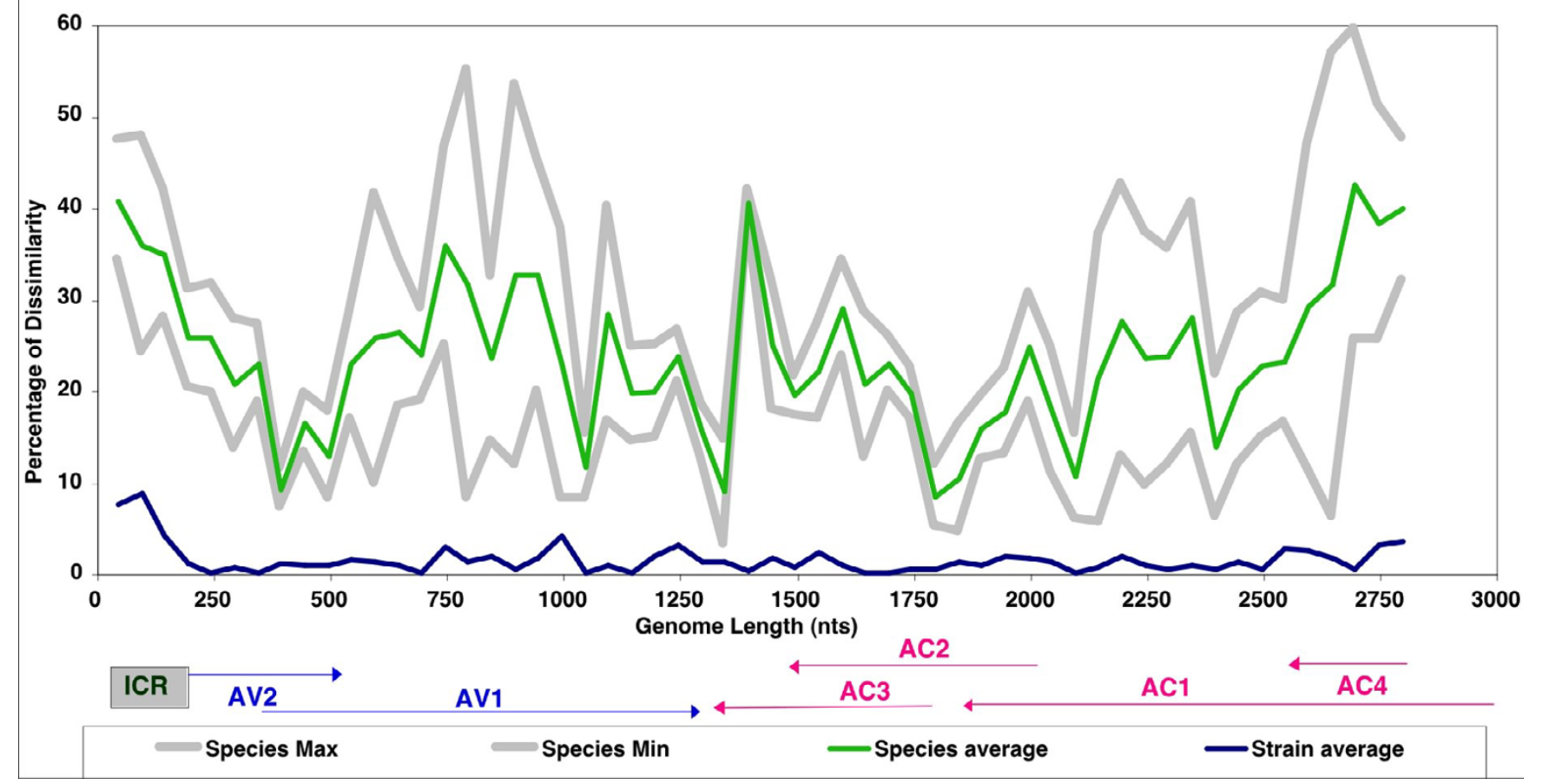

Figure I

(A) Pairwise analysis of begomoviruses in the Old World that do not exhibit putative recombinant fragments at the species level (green curve) and at the strain level (blue curve). (B) Pairwise analysis of EACMCV-[TZI] A component, paired with the sequence of the A component of other cassava mosaic geminiviruses like EACMCV-[TZ7] (blue line), ACMV-[TZ] (brown line), EACMV-[KE] (red line) and EACMZV-[ZB] (green line), showing the recombinant fragment of this virus (I200 - 2000 $n t s)$ as well as the one from EACMZV-[ZB] $(2000-2900 \mathrm{nts})$. The linearized genome organization of these geminiviruses is depicted at the bottom of the graph.

members of different species [5]. However, viruses that share between 80 and $90 \%$ sequence identity are often found to be recombinants [2], therefore, in the PCSA, we consider viruses sharing less than $80 \%$ identity as different species. PCSA profiles were carried out between sequences of different species and of different isolates and an average profile for the considered cluster of viruses was calculated for these two categories with increments of 50 nts along the genome sequence. A standard deviation value for each segment was calculated and minimum and maximum values corresponding to two standard deviation values were also calculated (Fig. 1). Each chosen pairwise analysis for putative recombinant sequences was then compared to the species average profile and the pertaining of each $50 \mathrm{nts}$ fragment to this category is examined. Segments different from more than 2 standard deviation values were considered to be putative recombined fragments. For each PCSA, a putative recombination percentage for the genome is calculated and a corresponding map can be drawn. It is verified (a posteriori) that the particular representatives of species and isolates selected for the 'Species and Isolate Average Curves' are $100 \%$ non-recombinant at the time of the analysis [20]. No statistical test is applied to PCSA.

\section{Competing interests}

The author(s) declare that they have no competing interests.

\section{Authors' contributions}

Design and conception of the study (JN, JPL, TASA, GT, $\mathrm{CMF}$ ); execution of the experiments (JN); manuscript preparation (JN, JPL, CMF); sequence analysis, alignment and phylogeny (JN, CMF). All authors read and approved the final manuscript.

\section{Acknowledgements}

This study was funded by the Crop Protection Programme of the UK's Department for International Development (DFID) through the Tropical Whitefly IPM Project of the System-wide Programme for Integrated Pest Management (SP-IPM). SP-IPM is an inter-centre programme established by the Consultative Group for International Agricultural Research (CGIAR). The senior author was also supported through a graduate fellowship from the International Institute of Tropical Agriculture (IITA) and by the Donald Danforth Plant Science Center, which supported some of the costs in St. 
Louis. The assistance of Mr. Cyprian Alloyce Rajabu of Plant Protection Division in Mwanza during sample collection is highly appreciated. Special thanks are due to other colleagues for helping in various ways, especially Dr. Justin Pita of the Noble Research Foundation, Ardmore, Oklahoma, USA, and Ismaël Ben F. Fofana of the International Laboratory of Tropical Agricultural Biotechnology (ILTAB), Donald Danforth Plant Science Center, St. Louis, MO, USA for his technical assistance. The views expressed do not necessarily represent those of DFID.

\section{References}

1. Stanley J, Bisaro DM, Briddon RW, Brown JK, Fauquet CM, Harrison BD, Rybicki EP, Stenger DC: Geminiviridae. In Virus Taxonomy, VIIIth Report of the ICTV 8th edition. Edited by: Fauquet CM, Mayo MA Maniloff J, Desselberger U and Ball LA. London, Elsevier/Academic Press; 2004:30I-326.

2. Fauquet $C M$, Stanley J: Geminivirus classification and nomenclature: progress and problems. Annals of Applied Biology 2003, 142:165-189.

3. Varma A, V.G. M: Emerging geminivirus problems: A serious threat to crop production. Annals of Applied Biology 2003, 142: 145-164.

4. Legg J, Fauquet CM: Cassava Mosaic Geminiviruses in Africa. Plant Molecular Biology 2004, 56:585-599.

5. Fauquet CM, Bisaro DM, Briddon RW, Brown JK, Harrison BD Rybicki EP, Stenger DC, Stanley J: Revision of taxonomic criteria for species demarcation in the family Geminiviridae, and an updated list of begomovirus species. Archives of Virology 2003, | 48:405-42].

6. Stanley J: Analysis of African cassava mosaic virus recombinants suggests strand nicking occurs within the conserved nonanucleotide motif during the initiation of rolling circle DNA replication. Virology 1995, 206:707-7।2.

7. Deng D, Otim-Nape WG, Sangare A, Ogwal S, Beachy RN, Fauquet CM: Presence of a new virus closely related to East African cassava mosaic geminivirus, associated with cassava mosaic outbreak in Uganda. African Journal of Root and Tuber Crops 1997. 2:23-28.

8. Zhou X, Liu Y, Calvert L, Munoz C, Otim-Nape GW, Robinson DJ, Harrison BD: Evidence that DNA-A of a geminivirus associated with severe cassava mosaic disease in Uganda has arisen by interspecific recombination. Journal of General Virology 1997, 78:210I-2III.

9. Fondong VN, Pita JS, Rey ME, de Kochko A, Beachy RN, Fauquet CM: Evidence of synergism between African cassava mosaic virus and a new double-recombinant geminivirus infecting cassava in Cameroon. Journal of General Virology 2000, 81:287-297.

10. Pita JS, Fondong VN, Sangare A, Otim-Nape GW, Ogwal S, Fauquet CM: Recombination, pseudorecombination and synergism of geminiviruses are determinant keys to the epidemic of severe cassava mosaic disease in Uganda. Journal of General Virology 200I, 82:655-665.

11. Ogbe FO, Legg J, Raya MD, Muimba-Kankalongo A, Theu MP, Kaitisha G, Phiri NA, Chalwe A: Diagnostic survey of cassava mosaic viruses in Tanzania, Malawi and Zambia. Roots 1997, 4:12-15.

12. Maruthi MN, Colvin J, Seal S, Thresh JM: First report of a distinct begomovirus infecting cassava from Zanzibar. Plant Disease 2002, 86: 187.

13. Ndunguru J, Legg JP, Aveling T, Thompson G, Fauquet CM: Restriction and sequence analysis of PCR-amplified viral DNAs suggests the existence of different cassava mosaic geminiviruses associated with cassava mosaic disease in Tanzania. Annals of Applied Biology in press.

14. Padidam M, Sawyer S, Fauquet CM: Possible emergence of new geminiviruses by frequent recombination. Virology 1999, 265:218-225.

15. Zhou X, Robinson DJ, Harrison BD: Types of variation in DNA $A$ among isolates of East African cassava mosaic virus from Kenya, Malawi and Tanzania. Journal of General Virology 1998, 79:2835-2840.

16. Berrie LC, Rybicki EP, Rey ME: Complete nucleotide sequence and host range of South African cassava mosaic virus: further evidence for recombination amongst begomoviruses. Journal of General Virology 200I, 82:53-58.
17. Saunders K, Salim N, Mali VR, Malathi VG, Briddon R, Markham PG, Stanley J: Characterisation of Sri Lankan cassava mosaic virus and Indian cassava mosaic virus: evidence for acquisition of a DNA B component by a monopartite begomovirus. Virology 2002, 293:63-74.

18. Hong YG, Robinson DJ, Harrison BD: Nucleotide sequence evidence for the occurrence of three distinct whitefly-transmitted geminiviruses in cassava. Journal of General Virology 1993, 74:2437-2443.

19. Harrison BD, Zhou X, Otim-Nape GW, Liu Y, Robinson DJ: Role of a novel type of double infection in the geminivirus-induced epidemic of severe cassava mosaic in Uganda. Annals of Applied Biology 1997, I 3 I:437-448.

20. Fauquet CM, Sawyer S, Idris AM, Brown JK: Sequence analysis and classification of apparent recombinant begomoviruses infecting tomato in the Nile and Mediterranean Basins. Phytopathology in press.

21. Legg JP: Emergence, spread and strategies for controlling the pandemic of cassava mosaic virus disease in east and central Africa. Crop Protection 1999, 18:627-637.

22. Myers N, Mittermeier R, Mittermeier C, da Fonseca G, Kent J: Biodiversity hotspots for conservation priorities. Nature 2000 , 403:853-858.

23. Fargette D, Pinel A, Abubakar Z, Traore O, Brugidou C, Fatogoma S, Hebrard E, Choisy M, Sere Y, Fauquet C, Konate G: Inferring the evolutionary history of rice yellow mottle virus from genomic, phylogenetic, and phylogeographic studies. Journal of Virology 2004, 78:3252-326I.

24. Legg JP, Ogwal S: Changes in the incidence of African cassava mosaic virus disease and the abundance of its whitefly vector along south-north transects in Uganda. Journal of Applied Entomology 1998, I 22:169-178.

25. Fauquet CM, Fargette D: African cassava mosaic virus; etiology, epidemiology and control. Plant Disease 1990, 76:404-4II.

26. Dellaporta SL, Wood J, Hicks JB: A plant DNA minipreparation: version II. Plant Molecular Biology Reporter 1983, I: I9-2I.

27. Swofford DL, Begle DP: PAUP: Phylogenetic Analysis Using Parsimony, Version 3.I. Champaign, II., Center for Biodiversity, Illinois Natural History Survey; 1993.

Publish with BioMed Central and every scientist can read your work free of charge

"BioMed Central will be the most significant development for disseminating the results of biomedical research in our lifetime. "

Sir Paul Nurse, Cancer Research UK

Your research papers will be:

- available free of charge to the entire biomedical community

- peer reviewed and published immediately upon acceptance

- cited in PubMed and archived on PubMed Central

- yours - you keep the copyright
BiolMedcentral 